\title{
ChondRophycus anabeliae ANd LauRencia digitata (Ceramiales, Rhodophyta) ARE RECORDED FOR THE FIRST TIME FOR VENEZUELA EXPANDING THEIR GEOGRAPHIC DISTRIBUTIONS BEYOND THE TYPE LOCALITIES
}

\section{ChondRophycus anabeliae y LAURENCIA DigItATA (CERAMIALES, RHODOPHYTA) SE REGISTRAN POR PRIMERA VEZ PARA VENEZUELA EXPANDIENDO SUS DISTRIBUCIONES GEOGRÁFICAS MÁS ALLÁ DE LAS LOCALIDADES TIPO}

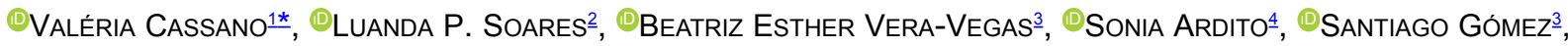 \\ (DAbel Sentíes ${ }^{5}$, DMutue T. FuJII²
}

\begin{abstract}
1'Departamento de Botânica, Universidade de São Paulo, São Paulo, Brazil.
${ }^{2}$ Núcleo de Pesquisa em Ficologia, Instituto de Botânica, São Paulo, Brazil.

${ }^{3}$ Centro de Botánica Tropical, Instituto de Biología Experimental, Facultad de Ciencias, Universidad Central de Venezuela, Caracas, Venezuela.

${ }^{4}$ Departamento de Biología, Facultad Experimental de Ciencias y Tecnología, Universidad de Carabobo, Valencia, Venezuela. ${ }^{5}$ Departamento de Hidrobiología, Universidad Autónoma Metropolitana-Iztapalapa, Cd. de Mexico, Mexico.
\end{abstract}

*Author for correspondence: vcassano@usp.br

\begin{abstract}
Background: Over the course of approximately 12 years, the species of the Laurencia complex have been systematically studied in the tropical and subtropical Atlantic Ocean, showing high diversity (48 species), which has been underestimated for the coast of Venezuela.

Questions: What is the species diversity of the Laurencia complex in Venezuela?

Studied species: Chondrophycus anabeliae, Laurencia digitata.

Study site and dates: Cayo Muerto, Parque Nacional Morrocoy, Estado Falcón, Venezuela, 2015.

Methods: For molecular studies, the plastid $r b c \mathrm{~L}$ gene and the mitochondrial DNA barcode marker COI-5P were used, combined with the study of current morpho-anatomical characters used for the identification of the species of the complex.

Results: The occurrence of Chondrophycus, as currently circumscribed, was confirmed for the first time for Venezuela. Chondrophycus anabeliae and Laurencia digitata are reported for the first time beyond the type localities. Tetrasporophytes are described for the first time for L. digitata.

Conclusions: Our findings expand the geographic distribution of Ch. anabeliae and L. digitata for the Venezuelan Caribbean and the Atlantic Ocean, respectively.

Keywords: COI-5P, phylogeny, $r b c \mathrm{~L}$, Rhodomelaceae, taxonomy.

\section{Resumen}

Antecedentes: A lo largo de aproximadamente 12 años se han estudiado de manera sistemática a las especies del complejo Laurencia en el Océano Atlántico tropical y subtropical, evidenciando una alta diversidad (48 especies), misma que se ha subestimado para la costa de Venezuela.

Preguntas: ¿Cuál es la diversidad de especies del complejo Laurencia en Venezuela?

Especies de estudio: Chondrophycus anabeliae, Laurencia digitata.

Sitio y años de estudio: Cayo Muerto, Parque Nacional Morrocoy, Estado Falcón, Venezuela, 2015.

Métodos: Para los estudios moleculares, se utilizaron el gen del plástido $r b c \mathrm{~L}$ y el marcador mitocondrial del código de barras de ADN, COI-5P, combinado con el estudio de los caracteres morfoanatómicos actuales utilizados para la identificación de las especies del complejo.

Resultados: La presencia del género Chondrophycus, como se circunscribe actualmente, se confirmó por primera vez para Venezuela. Chondrophycus anabeliae y Laurencia digitata se registran por primera vez fuera de sus localidades tipo. Los tetrasporofítos se describen por primera vez para $L$. digitata.

Conclusiones: Nuestros hallazgos amplían la distribución geográfica de Ch. anabeliae y L. digitata para el Caribe venezolano y el Océano Atlántico, respectivamente.

Palabras clave: COI-5P, filogenia, $r b c \mathrm{~L}$, Rhodomelaceae, taxonomía.
\end{abstract}


Chondrophycus anabeliae and Laurencia digitata from Venezuela

The Laurencia complex encompasses an extremely diverse group of marine red macroalgae in which new species and genera have been defined in the last three decades (Nam et al. 1994, Garbary \& Harper 1998, Nam 2007, MartinLescanne et al. 2010, Cassano et al. 2012b, 2019, Metti et al. 2015, Machín-Sánchez et al. 2016, Sentíes et al. 2016, 2019, Francis et al. 2017, Rousseau et al. 2017, ColladoVides et al. 2018, Bibi et al. 2019). The complex is comprised of 394 species, of these, 211 have been taxonomically accepted at this time (Guiry \& Guiry 2020), distribuited in eight genera: Laurencia sensu stricto J.V.Lamouroux, Osmundea Stackhouse, Chondrophycus (Tokida \& Y.Saito) Garbary \& J.T.Harper, Palisada K.W.Nam, Yuzurua (K.W.Nam) Martin-Lescanne, Laurenciella Cassano, Gil-Rodríguez, Sentíes, Díaz-Larrea, M.C.Oliveira \& M.T.Fujii, Corynecladia J.Agardh, and Ohelopapa F.Rousseau, Martin-Lescanne, Payri \& L.Le Gall. Laurencia s.s. is the most speciose genus of the complex, with 138 species accepted taxonomically around the world (Guiry \& Guiry 2020), whereas Chondrophycus is much less representative, with 16 species accepted taxonomically, mostly cited for the Indo-Pacific Ocean. Chondrophycus anabeliae Sentíes, M.T.Fujii, Cassano \& Dreckmann is the only species of the genus reported for the western Atlantic Ocean (Sentíes et al. 2016, Wynne 2017).

Venezuela is an important area of occurrence of species of the Laurencia complex in the Atlantic. To date, 16 species and one variety have been reported: nine of Laurencia, four of Palisada, two of Osmundea and one of Yuzurua. However, the genera Chondrophycus (as currently circumscribed), Corynecladia, Laurenciella and Ohelopapa were not mentioned in the region (Rodríguez de Ríos 1979, Ganesan 1989, Gómez et al. 2020). Of the species cited for Venezuela, some are rare or endemic. Laurencia foldatsii N.Rodríguez Ríos is endemic to Venezuela (Rodríguez de Ríos 1981, Hernández et al. 2017); Laurencia gracilis J.D. Hooker \& Harvey [as Laurencia filiformis J.D.Hooker \& Harvey nom. illeg.] is rare in the Atlantic; apart from Venezuela it is quoted only for the Indo-Pacific; and Osmundea pinnatifida (Hudson) Stackhouse and Osmundea oederi (Gunnerus) G.Furnari (= Laurencia bolivarii N.Rodríguez Ríos) are rare in the western Atlantic. The citations of the Laurencia complex species in Venezuela are mostly based on morpho-anatomical characters; only Laurencia natalensis Kylin was studied based on molecular data (García-Soto \& Lopéz-Bautista 2019).

During our study of the Laurencia complex in the tropical and subtropical Atlantic, we identified two species not yet reported for the Venezuelan coast using molecular markers, $r b c \mathrm{~L}$ and COI-5P, combined with morphological data. Our findings confirm the occurrence of the genus Chondrophycus for Venezuela, expanding the geographic distribution of $C h$. anabeliae beyond the type locality, and of Laurencia digitata Francis, Bolton, Mattio \& R.J. Anderson to the Atlantic Ocean.

\section{Materials and methods}

Samples of Chondrophycus anabeliae and Laurencia digitata were collected in Cayo Muerto, Parque Nacional Morrocoy, Estado Falcón, Venezuela $\left(10^{\circ} 55^{\prime} 48.08^{\prime}\right.$ N, $\left.68^{\circ} 15^{\prime} 31.73^{\prime \prime} \mathrm{W}\right)$ in 2015. For each sample, small fragments of the thallus were dried in silica gel for molecular analyses, and the remaining material was preserved in $4 \%$ formalin-seawater or pressed as herbarium vouchers for morphological studies. For morphological examination, transverse and longitudinal hand sections were stained with $0.5 \%$ aqueous aniline blue and acidified with $1 \mathrm{~N} \mathrm{HCl}$. For each specimen studied, a minimum of 20 measurements of each morphometric character were made. Measurements are given as length $\times$ diameter. Images of whole specimens were taken with a Sony W5 digital camera (Sony, Tokyo, Japan), and details of branches and branchlets were captured with Sony W5 coupled to a Stemi SV 6-Zeiss stereomicroscope (Zeiss, Göttingen, Germany). Microscopic diagnostic features were taken with the Sony W5 coupled to a Nikon Eclipse E-200 optical microscope (Nikon, Tokyo, Japan). Voucher specimens were deposited in the herbaria of University of São Paulo (SPF) and Botanical Institute, São Paulo (SP), University of Carabobo, Venezuela (LUC), and Metropolitan Autonomous University (UAMIZ). Abbreviations follow Index Herbariorum (Thiers 2020).

For molecular studies, DNA extraction followed manufacturer's instructions of the DNeasy Plant Mini Kit (Qiagen, Valencia, USA). PCR protocols for both markers followed Cassano et al. (2019), using for $r b c \mathrm{~L}$ the following pairs of primers: FrbcLstart-R492, F492-R1150 and F993$\mathrm{RrbcS}$ (Freshwater \& Rueness 1994), and for COI-5P the primer pair GAZF1-GAZR1 (Saunders 2005). For PCR amplification was used the PCR Master Mix (Promega, Madison, Wisconsin USA) in a final volume of $25 \mu \mathrm{l}$. The reactions were performed in a Techne TC-4000 thermocycler (Bibby Scientific, Staffordshire, UK). All PCR products were analyzed by electrophoresis in $1 \%$ agarose to check product size and were purified with MicroSpinTMS-300 HR Columns (GE Healthcare Life Sciences, Piscataway, New Jersey, USA) as per manufacturer's instructions.

Sequencing reactions were made using the same PCR primers mentioned above, and the BigDye Terminator Cycle Sequencing Ready Reaction kit (Applied Biosystems, Foster City, California, USA) on an ABI PRISM 3730 Genetic Analyzer (Applied Biosystems). Consensus sequences and multiple sequence alignments for both $r b c \mathrm{~L}$ and COI-5P were generated using BioEdit 7.0.4.1 software (Hall 1999). Multiple sequence alignment for $r b c \mathrm{~L}$ consisted of 93 sequences, including three newly generated sequences from Cayo Muerto, Venezuela; the remaining 
sequences were downloaded from GenBank (Appendix 1). Three Rhodomelacean species were used as outgroups, Chondria acrorhizophora Setchell \& N.L.Gardner, Chondria collinsiana M.Howe, and Chondria dasyphylla (Woodward) C.Agardh (Appendix 1). Neighbor-joining (NJ) analysis was conducted in PAUP v4.0 beta10 (Swofford 2002) with 2,000 bootstrap replicates. The most appropriate model of sequence evolution for maximum likelihood (ML) and Bayesian inference (BI) was selected using jModeltest v2.1.10 (Darriba et al. 2012) under the Akaike information criterion (AIC) as implemented on the online server CIPRES Science Gateway v3.3 (Miller et al. 2010). The model selected was the general-time-reversible model of nucleotide substitution with invariant sites and gamma-distributed rates for the variable sites $(\mathrm{GTR}+\mathrm{I}+\mathrm{G})$. Maximum likelihood (ML) analysis was performed using IQ-Tree v1.4.3 (Nguyen et al. 2015) with 1,000 boostrap replicates on the IQ-Tree web portal. BI analysis was performed using MrBayes v3.2.2 (Ronquist et al. 2012). For $\mathrm{BI}$ analysis, two runs with four MCMC chains (one hot and three cold) were conducted with 4,000,000 generations and sampling every 1,000 generations, starting with a random tree. The first 100,000 generations in both runs were discarded as burn-in to build the consensus tree.

Multiple sequence alignment for COI-5P consisted of 69 sequences, including three newly generated sequences; the remaining were downloaded from GenBank (Appendix 1). One Rhodomelacean species was used as outgroup, Chondria baileyana (Montagne) Harvey (Appendix 1). The neighbor-joining (NJ) analysis was conducted in PAUP with 2,000 bootstrap replicates. Intra- and interspecific divergence values of $r b c \mathrm{~L}$ and COI-5P were calculated using uncorrected " $p$ " distances in PAUP.

\section{Results}

Molecular study. The $r b c \mathrm{~L}$ final alignment included 93 sequences of 1,448 bp in length.

The Chondrophycus clade had full support (Figure 1). The two $r b c \mathrm{~L}$ sequences of Chondrophycus anabeliae from Venezuela were identical and formed a subclade with Ch. anabeliae from Mexico, its type locality, with high to moderate supports (Figure 1), diverging by $1.34 \%$. This subclade was sister to Chondrophycus sp. 3 from New Caledonia plus Chondrophycus sp. from Australia from which it diverged by 5.17-5.9\%. The subclade formed by Chondrophycus cf. undulatus (Yamada) Garbary \& J.T.Harper, Ch. sp.1, Ch. sp. 2 from New Caledonia, Chondrophycus dotyi (Y.Saito) K.W.Nam from Hawaii, and Chondrophycus tronoi (E.Ganzon-Fortes) K.W.Nam from Philippines diverged by $1.86 \%$ (Ch. sp.1 vs $C h$. cf. undulatus) to $6.4 \%$ (Ch. doyti vs Ch. tronoi). The interspecific divergence within Chondrophycus genus ranging from $1.86 \%$ to $7.8 \%$ (Ch. anabeliae from Mexico vs Ch. sp.1 from New Caledonia).

Laurencia s.s. clade was highly supported (Figure 1). The $r b c \mathrm{~L}$ sequence of $L$. digitata from Venezuela joined with $L$. digitata from South Africa, its type locality, with high to moderate support, diverging by $0.85 \%$. Laurencia digitata is sister to Laurencia cf. kuetzingii A.J.K.Millar from New Caledonia, diverging by $2.14-2.19 \%$. This subclade was resolved as sister to Laurencia pumila (Grunow) Papenfuss plus L. pumila var. dehoopiensis Francis, Bolton, Mattio \& R.J.Anderson from South Africa plus Laurencia karachiana Bibi, Cassano \& Rasheed from Pakistan with high to moderate supports. The interspecific divergence between sequences of $L$. digitata and $L$. pumila plus L. pumila var. dehoopiensis was 4.36-4.89\%, whereas L. digitata diverged from L. karachiana by 4.7-4.9\%.

The COI-5P final alignment included 69 sequences of $644 \mathrm{bp}$ in length (Figure 2). We were unable to obtain COI-5P sequence for $L$. digitata from Venezuela due to contamination, even after several amplification attempts. The two identical COI-5P sequences of Ch. anabeliae fromVenezuela joined to the sequence of $\mathrm{Ch}$. anabeliae from the type locality generated in this study (MN597440), diverging only by $0.3 \%$ (Figure 2 ). This subgroup joined to Chondrophycus succisus (A.B.Cribb) K.W.Nam (as Laurencia succisa A.B.Cribb) from Molokai (Hawaii, USA) with $5.4-5.7 \%$ of divergence. The subgroup formed by one sequence of Ch. dotyi and four of Ch. cf. undulatus, all from the Hawaiian Islands, showed low genetic divergence $(0.16-0.48 \%)$ suggesting that these samples represent the same taxonomic entity. The divergence between these two subgroups (Ch. anabeliae-Ch. succisus and Ch. dotyi-Ch. cf. undulatus) ranging from $8.13 \%$ to $8.76 \%$.

Morphological study. Chondrophycus anabeliae Sentíes, M.T.Fujii, Cassano \& Dreckmann in Sentíes et al. 2016:

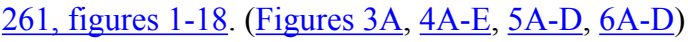

Type locality. Mexico, Quintana Roo, Isla Mujeres, Garrafón de Castilla; holotype UAMIZ 1240!

Description. Plants forming erect tufts up to $5 \mathrm{~cm}$ high, reddish-brown to yellowish-brown, terete to partially compressed axes (Figures 3A, $\underline{4 \mathrm{~A}}$ ), cartilaginous in texture, not adhering to herbarium paper when dried. Thalli attached to the substratum by a discoid holdfast. Erect branches irregularly alternate and spirally arranged, usually with 2-3 (4) orders of branches. The main axes are terete and first-order branches partially compressed mainly in the upper third portion of the thalli, up to $2,000 \mu \mathrm{m}$ in diameter, and slightly narrowing towards the terete apices. Ultimate branchlets cylindrical to clavate and truncate at the apices, $500-2,800 \mu \mathrm{m}$ long and 525-1,000 $\mu \mathrm{m}$ in diameter. 


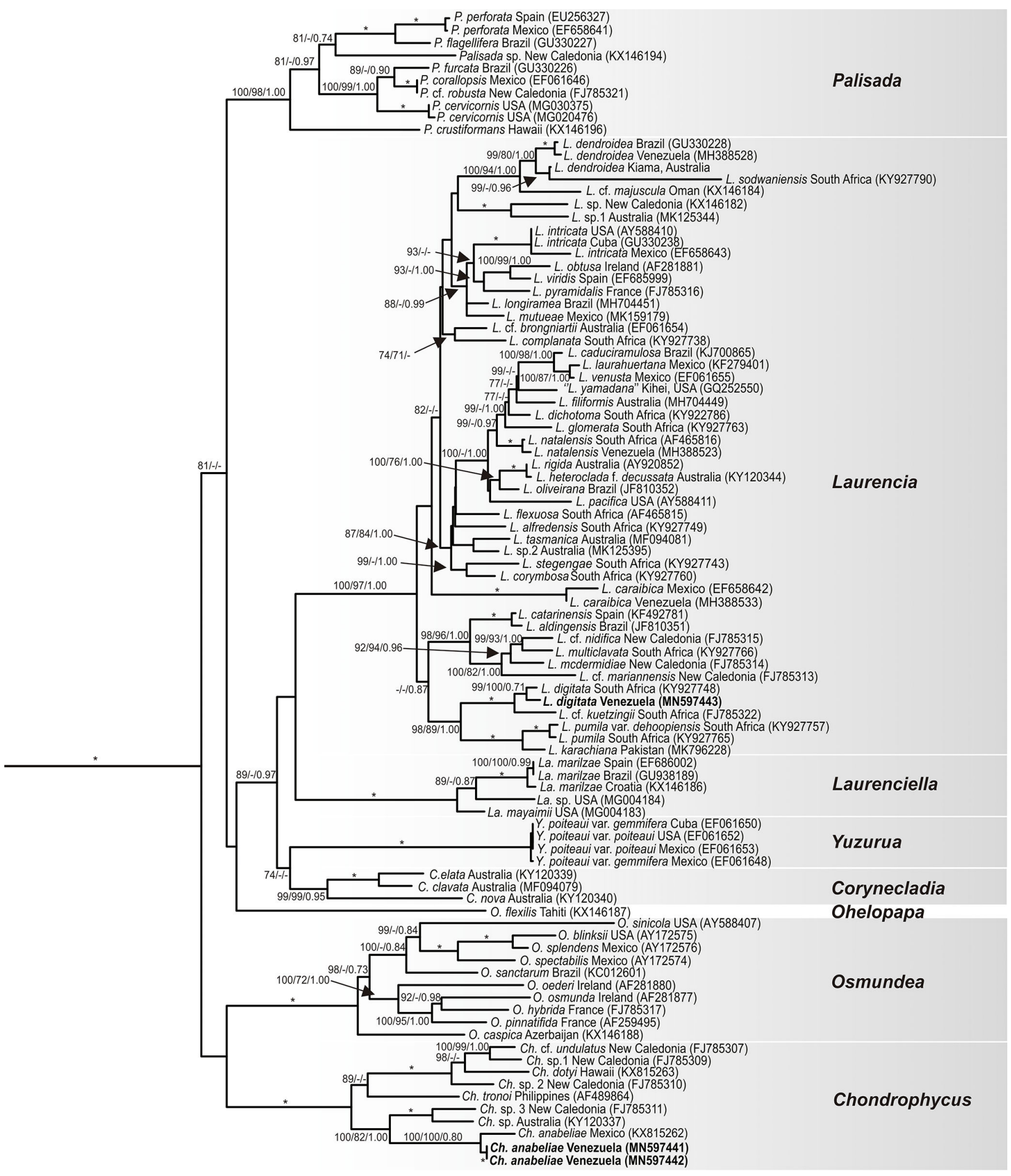

Figure 1. Consensus tree derived from Maximum likelihood (ML) analyses of $r b c \mathrm{~L}$ sequences. Bootstrap supports for NJ (2000 replicates)/ML (1000 replicates)/posterior probabilities, PP $<0.95$ are given at the nodes. Sequence generated in this study in bold; indicates lack of bootstrap support or values under 70 ; *indicates full support. Outgroups were removed from the figure only for better ingroups viewing. 
Cassano et al. / Botanical Sciences 98(4): 624-643. 2020

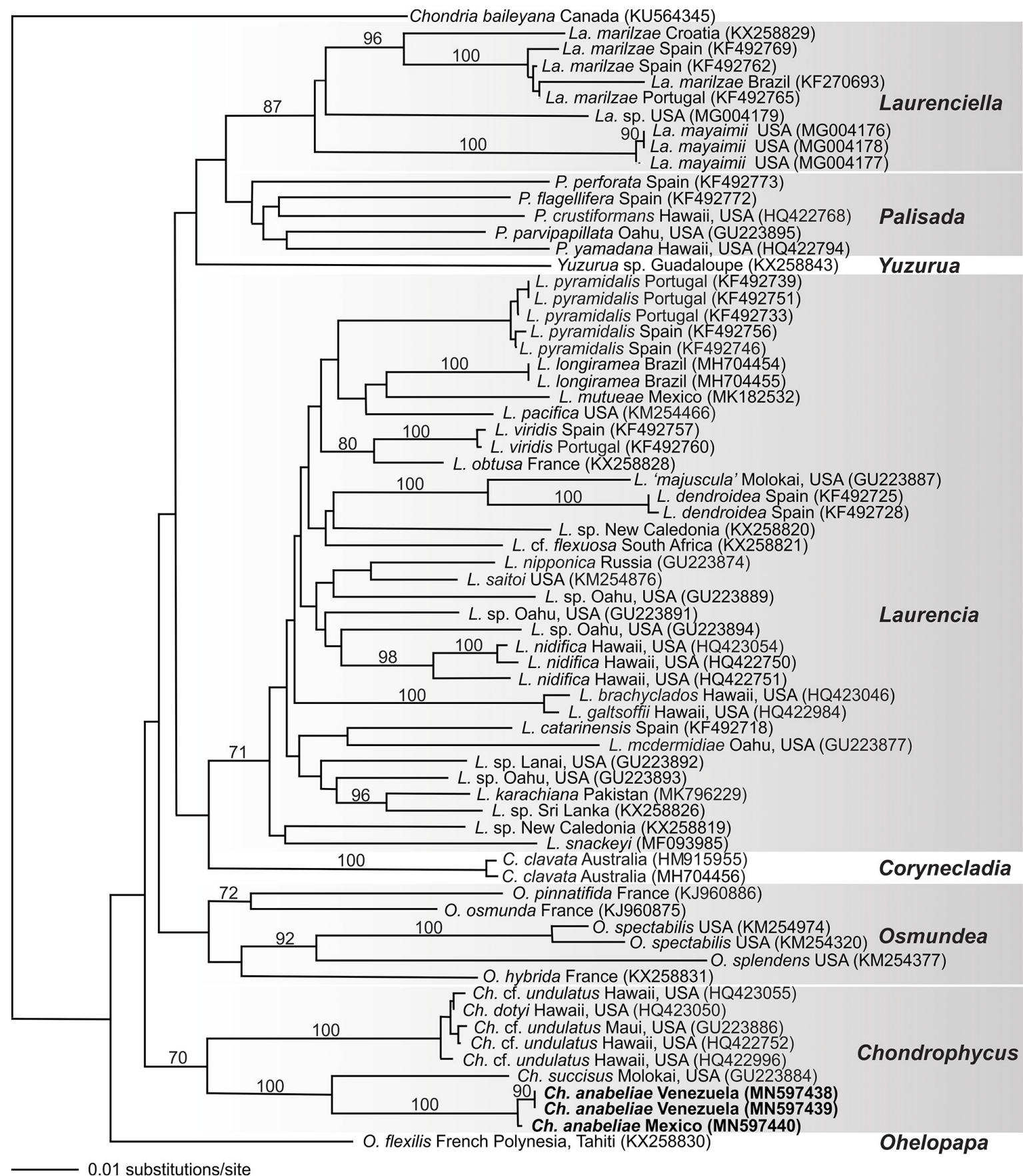

Figure 2. NJ analysis for COI-5P sequences. Bootstrap values (2000 replicates) are shown at nodes; values under 70 were not considered. Sequence generated in this study in bold. 


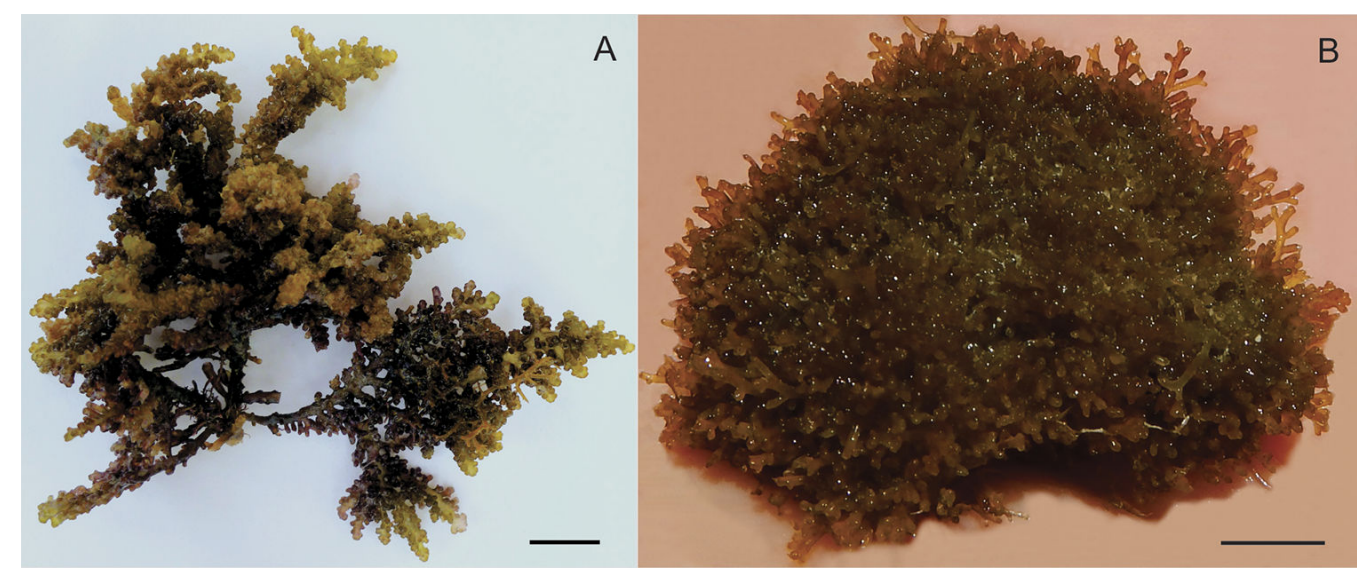

Figure 3. A) Habit of Chondrophycus anabeliae. B) Habit of Laurencia digitata. Living materials. Scale bar: A and B, $1 \mathrm{~cm}$.

In surface view, the outermost cortical cells are translucent, isodiametric-polygonal in the middle portions, 17.5-32.5 $\times$ 17.2-37.5 $\mu \mathrm{m}$ without secondary pit connections (Figure 4B). Subcortical cells are pigmented, larger and connected to each other by secondary pit connections (Figure 4C). Outermost cortical cells translucent and subcortical cells present 1 (-2) crystals per cell (Figure 4C, D). In transverse section, thalli formed by two cortical cell layers, and four or five layers of medullary cells (Figure 4E). The cortical cells of translucent outer layer are quadratic, cuneiform to rectangular, smaller than the inner layer cells, measuring $17.5-30 \times 22.5-30 \mu \mathrm{m}$ in the ultimate branchlets (Figure 5A), and elongated, 47.5$55 \times 27.5-35 \mu \mathrm{m}$ in the middle portions of main axes. The inner layer of cortical cells is composed of pigmented and elongated cells, measuring 40-65 $\times 35-50 \mu \mathrm{m}$ (Figure $5 \mathrm{~B}$ ) in the middle portions of main axes. Medullary cells are rounded or slightly radially elongated, measuring 65$145 \times 47.5-107.5 \mu \mathrm{m}$ in the middle portions of the main axes. Medullary cell walls uniformly thickened, but lenticular wall thickenings are absent. Each vegetative axial segment cuts off two pericentral cells (Figure 5C) that are slightly smaller than the medullary cells of the surrounding layer. In median longitudinal sections through a branchlet, the outer cortical cell walls near the apices are markedly projecting beyond the surface (Figure 5D).

Tetrasporangial branchlets are cylindrical or slightly compressed, simple or compound, 500-1,500 $\times 575-825 \mu \mathrm{m}$ (Figure 6A). At the apex of fertile branches, each axial segment produces one fertile additional pericentral cell situated oppositely to the pre-existing two pericentral cells which remain vegetative (Figure 6B). The additional cell cuts off two pre-sporangial cover cells distally abaxially positioned in relation to the tetrasporangial initial (Figure 6C). Subsequently, one post-sporangial cover cell is produced and continues to divide, contributing to cortication around the tetrasporangia. Tetrasporangia are arranged in a right-angled pattern in relation to fertile branchlets (Figure 6D). Mature tetrasporangia are tetrahedrally divided, $50-100 \mu \mathrm{m}$ in diameter. Gametangia were not observed.

Examined material. Venezuela. Estado Falcón: Parque Nacional Morrocoy, Cayo Muerto, 19 May 2015, tetrasporophyte, S. Ardito, M.T. Fujii, A. Senties, V. Cassano (SPF58487, SP470468, LUC7611, UAMIZ 1405). GenBank accession number for $r b c \mathrm{~L}$ (MN597441, MN597442) and for COI-5P (MN597438, MN597439).

Distribution and habitat. This species is currently recorded only for Mexico (Sentíes et al. 2016), and Venezuela (this study). Epilithic specimens were collected growing in shallow waters on rocky coastline, northeast of Cayo Muerto. The environment is considered as an intertidal zone with medium-sized rocks and moderately strong waves.

Laurencia digitata Francis, Bolton, Mattio \& R.J.Anderson in Francis et al. 2017: 812, Figure 5. (Figures 3B, 7A-F, $\underline{8 \mathrm{~A}-\mathrm{D})}$

Type locality. South Africa, KwaZulu-Natal, Cape Vidal; holotype BOL150572.

Description. Plants forming small, very intricate cushionlike tufts, up to $5 \mathrm{~cm}$ high, yellowish-brown, terete, cartilaginous in texture, adhering to herbarium paper when dried (Figure 3B). Thallus attached to the substratum by a discoid holdfast, and basal descending branches. Erect branches irregularly alternate and spirally arranged, with up to 3 orders of branches (Figure 7A). Main axes 275-525 $\mu \mathrm{m}$ in diameter in middle portion of the thallus. Ultimate branchlets are cylindrical to clavate with truncated tips, $452-950 \times 225-325 \mu \mathrm{m}$ in diameter. 
Cassano et al. / Botanical Sciences 98(4): 624-643. 2020

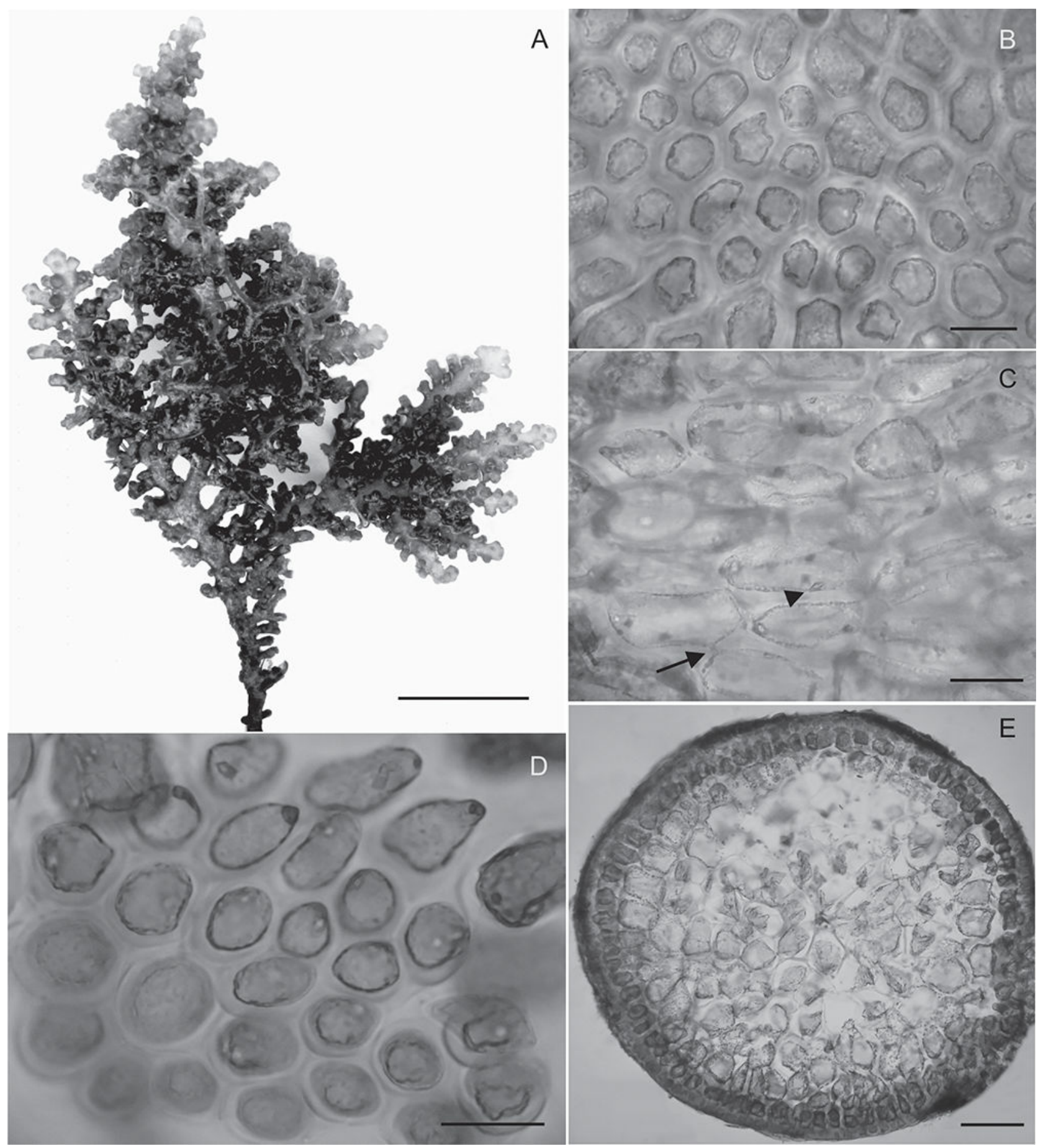

Figure 4. Chondrophycus anabeliae. A) Part of branches of a sterile plant. B) Surface view of translucent cortical cells. C) Surface view of subcortical cells. Note secondary pit connections between subcortical cells (arrow) and crystals (arrowhead). D) Surface view of translucent cortical cells showing one crystal per cell. E) Transverse section of the thallus. Scale bar: A, $1 \mathrm{~cm}$; B and D, $25 \mu \mathrm{m} ; \mathrm{C}, 50 \mu \mathrm{m} ; \mathrm{E}, 100 \mu \mathrm{m}$. 


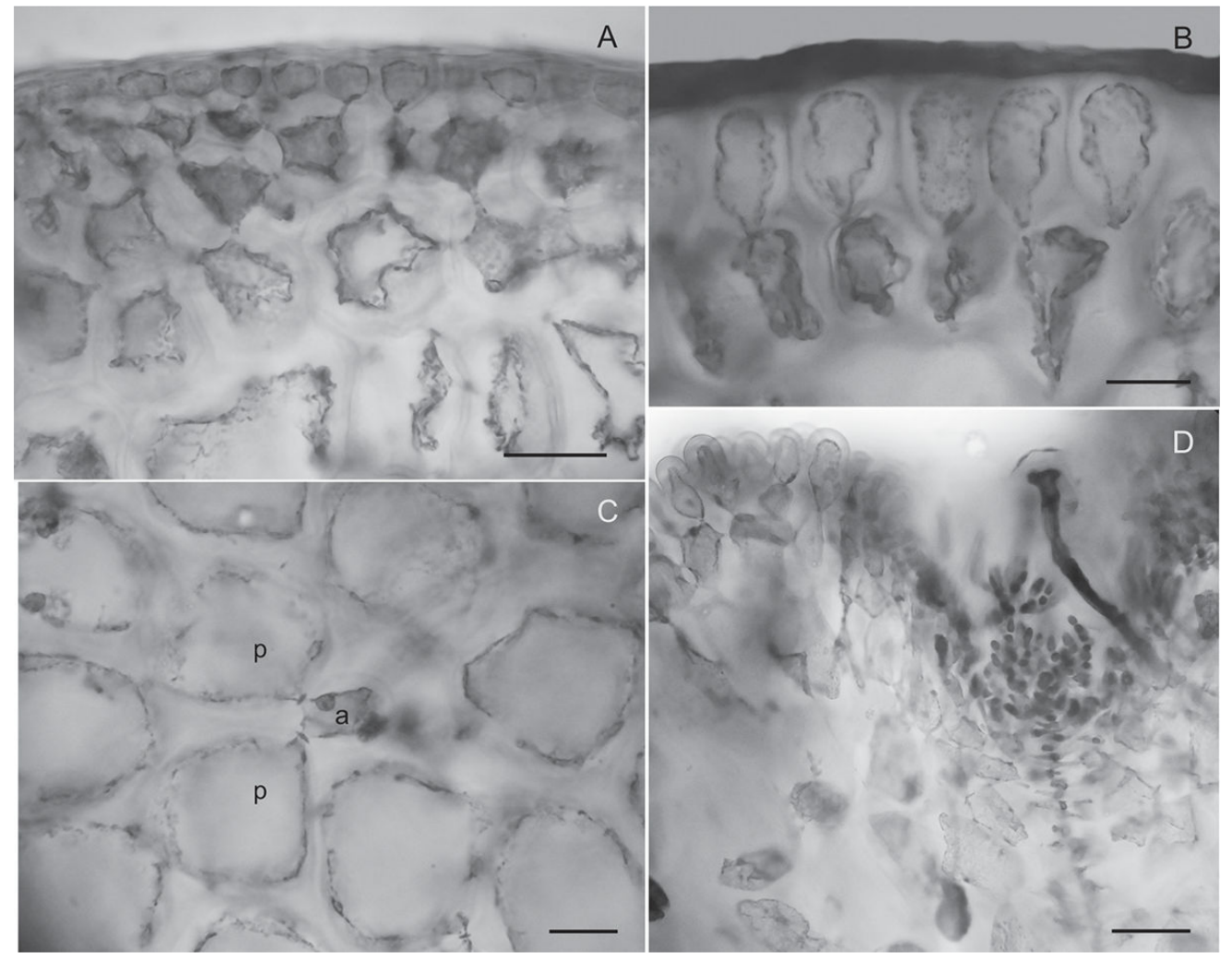

Figure 5. Chondrophycus anabeliae. A) Detail of the two-layered cortical cells of ultimate branchlets. Note small translucent outer cortical cells and large pigmented inner cortical cells with secondary pit connections between them. B) Detail of the two-layered cortical cells of main axes in the middle portions of the thallus. Note elongated translucent outer cortical cells. C) Transverse section of upper portion of branch showing an axial cell (a) with two pericentral cells (p). D) Longitudinal section through to a branchlet showing projecting cortical cells. Scale bar: A, D, $50 \mu \mathrm{m}$; B and C, $25 \mu \mathrm{m}$.

In surface view, cortical cells have $1(-2)$ corps en cerise per cell (Figure 7B $)$. Cortical cells are arranged regularly in longitudinal rows and connected to each other by longitudinally oriented secondary pit-connections (Figure 7C). Cortical cells are rounded to polygonal and slightly longitudinally elongated in middle portions of main axes, 37.5-57.5 $\times$ 27.5-50 $\mu \mathrm{m}$. In transverse section, the thallus has 1-2 layers of pigmented cortical cells and 3-4 layers of hyaline medullary cells (Figure 7D). Cortical cells are quadrate, cuneiform to rectangular, not arranged as a palisade, and 25-35 $\times 22.5-37.5 \mu \mathrm{m}$ in the middle portions of thalli. Medullary cells are rounded to slightly radially elongated, and 55-90 × 42.5-52.5 $\mu \mathrm{m}$, gradually increasing in size toward the center of the thallus. Each vegetative axial segment cut off four pericentral cells slightly larger than the other surrounding cells (Figure 7E). In median longitudinal sections through a branchlet, the outer cortical cell walls near the apices projecting beyond the surface (Figure 7F). Lenticular thickening absent.

Tetrasporangial branchlets are cylindrical, simple or compound, $575-2,125 \times 225-400 \mu \mathrm{m}$ (Figure 8A). At the apex of fertile branches, each axial segment produces one fertile pericentral cell, the fourth ones (Figure 8B), the other pericentral cells remain sterile. Fertile pericentral cell cuts off two pre-sporangial cover cells distally abaxially positioned in relation to the tetrasporangial initial (Figure 8D). Subsequently, one post-sporangial cover cell is produced and continues to divide, contributing to cortication around the tetrasporangia. Tetrasporangia are arranged in a parallel pattern in relation to fertile branchlets (Figure 8A, C). Mature tetrasporangia are tetrahedrally divided, 47.5-75 $\mu \mathrm{m}$ in diameter. Gametangia were not observed.

Material examined. Venezuela. Estado Falcón: Parque Nacional Morrocoy, Cayo Muerto, 19 May 2015, tetrasporophyte, S. Ardito, M.T. Fujii, A. Senties, V. Cassano (SPF58488, SP470469, UAMIZ 1406). GenBank accession number for $r b c \mathrm{~L}$ (MN597443).

Distribution and habitat. This species is currently recorded only for South Africa (Francis et al. 2017) and Venezuela (this study). Laurencia digitata was collected as drift specimens in shallow waters on rocky coastline, northeast of Cayo Muerto. The environment is considered as an intertidal zone with medium-sized rocks and moderately strong waves. 


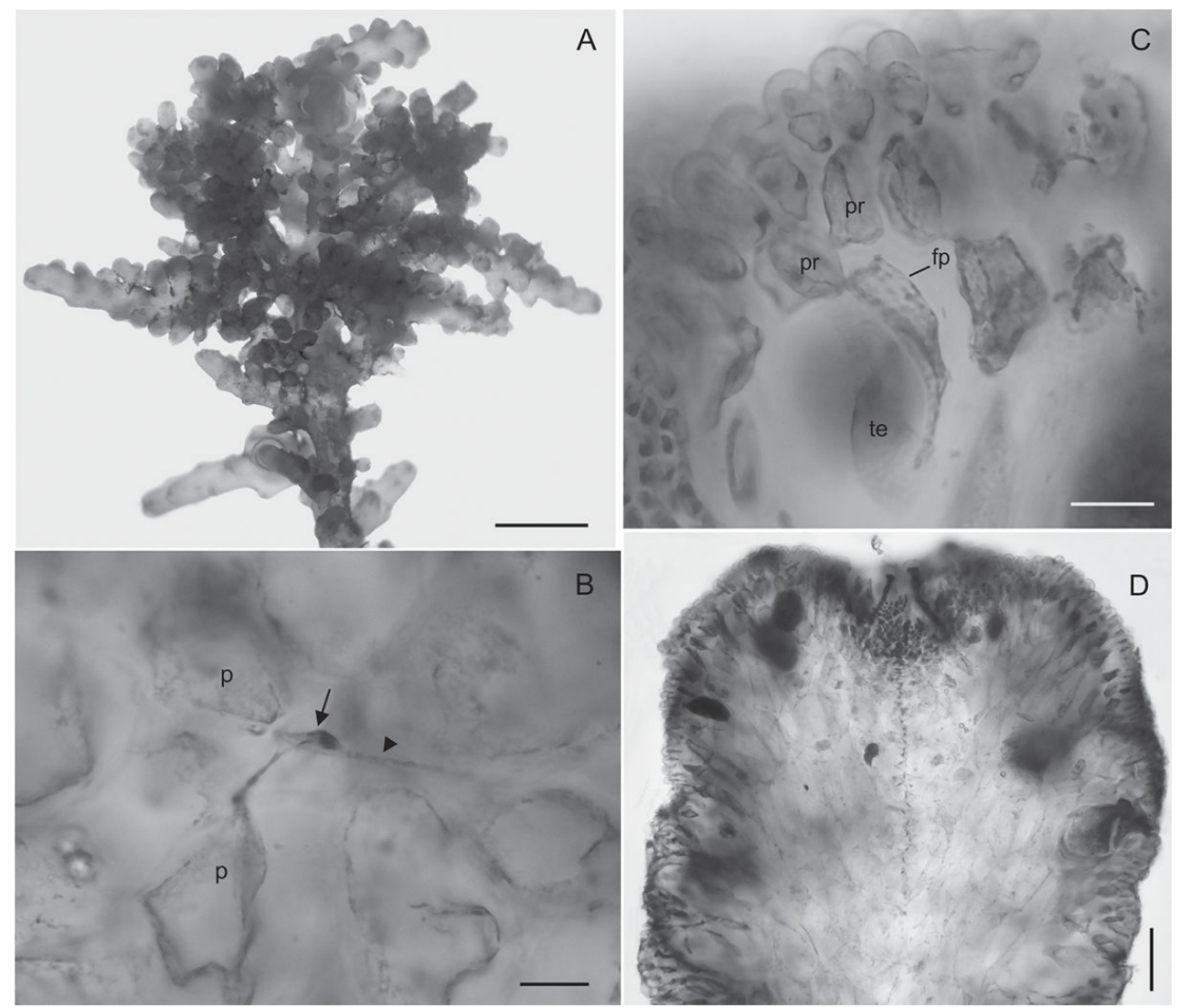

Figure 6. Chondrophycus anabeliae. A) Detail of tetrasporangial branches. B) Transverse section of tetrasporangial axial segment showing an axial cell (arrow) and two vegetative pericentral cells (p); an additional third fertile pericentral cell is formed in the opposite position (arrowhead). C) Detail of fertile pericentral cell (fp) with two pre-sporangial cover cells (pr), tetrasporangium (te, out of focus); postsporangial cover cell not shown. D) Longitudinal section through tetrasporangial branchlet showing right-angle arrangement of the tetrasporangia. Scale bar: A, $3 \mathrm{~mm}$; B and C, $25 \mu \mathrm{m}$; D, $100 \mu \mathrm{m}$.

\section{Discussion}

Comparison of $r b c \mathrm{~L}$ and COI-5P sequences of Ch. anabeliae from the type locality (Mexico) with our material confirmed the occurrence of this species on the Venezuelan coast, whereas $L$. digitata was confirmed only by comparison with $r b c \mathrm{~L}$ sequence from the type locality (South Africa), since we were unable to generate COI-5P sequences and there are also no sequences available of this marker in databases.

Considering our results for $r b c \mathrm{~L}$, intraspecific value between the Venezuelan and South African $L$. digitata $(0.85 \%)$ is within the range observed in previous works for Laurencia s.s. (0-1.35\%) reported by Cassano et al. (2012a, b), Metti et al. (2013), and Collado-Vides et al. (2018). Interspecific divergences for the $r b c \mathrm{~L}$ gene between L. digitata and Laurencia species closest molecularly (i.e., L. cf. kuetzingii, L. pumila, L. pumila var. dehoopiensis, and L. karachiana, 2.14-4.9 \%) were within the variation observed for Laurencia s.s. by Cassano et al. (2012b, 1.0-6.8 \%) and Cassano et al. $(2019,2.4-3.7 \%)$.
There are no data available in the literature for the $r b c \mathrm{~L}$ gene to compare the intraspecific divergence for Chondrophycus. However, the intraspecific value obtained for Ch. anabeliae $(1.34 \%)$ is below the interspecific variation range described for the genus by Cassano et al. (2012b, 1.8-6.9\%), by Sentíes et al. (2016, 3.4-7.8\%), and that found in this study (1.86-7.8\%).

For COI-5P gene, the intraspecific divergence values reported for the Laurencia complex are low, not exceeding $1 \%$. The lowest range of intraspecific divergence was observed in this study $(0-0.3 \%)$ for samples of Ch. anabeliae from the Caribbean Sea (Venezuela and Mexico), whereas divergences up to $0.52 \%$ were reported by Machín-Sánchez et al. (2014) for Laurencia, up to $0.67 \%$ by Machín-Sánchez et al. (2016) for Osmundea, and up to $0.7 \%$ by Cassano et al. (2012b), Machín-Sánchez et al. (2014), and Collado-Vides et al. (2018) for Laurenciella. The interspecific divergence obtained in this study for COI-5P (5.4-8.76\%) is within the range found for other genera of the complex, i.e. for Laurenciella species (7.4$9.2 \%$, Collado-Vides et al. 2018), and for Laurencia species (2.6-10.2\%, Cassano et al. 2019). 

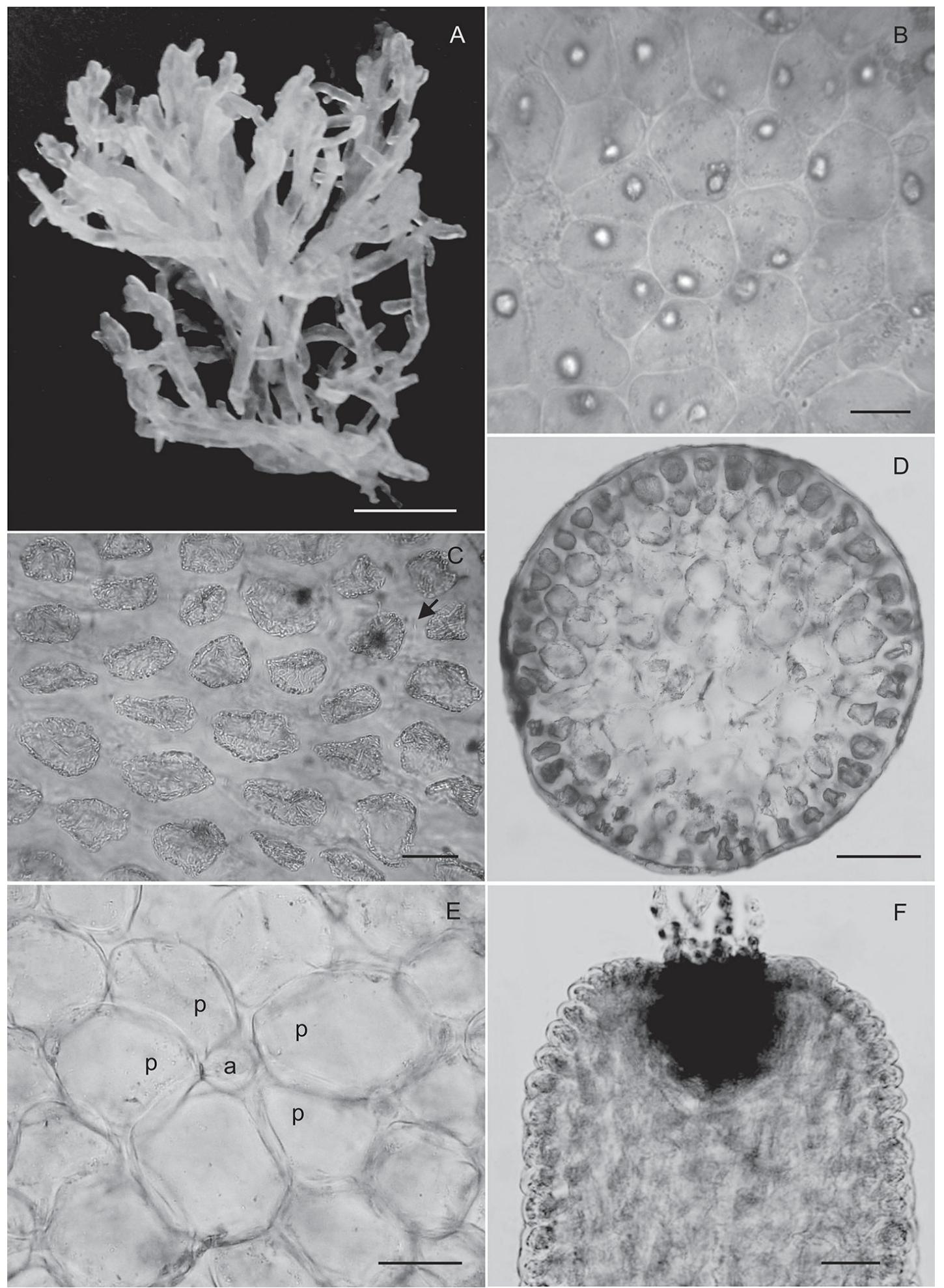

Figure 7. Laurencia digitata. A) Part of branches of a sterile plant. B) Surface view of cortical cells showing corps en cerise in living material. C) Surface view of cortical cells showing secondary pit-connections (arrow). D) Transverse section of the thallus. E) Transverse section of upper portion of branch showing an axial cell (a) with four pericentral cells (p). F) Longitudinal section through to a branchlet showing projecting cortical cells. Scale bar: A, $3 \mathrm{~mm}$; B and C, $25 \mu \mathrm{m}$; D, $100 \mu \mathrm{m}$; E and F, $50 \mu \mathrm{m}$. 


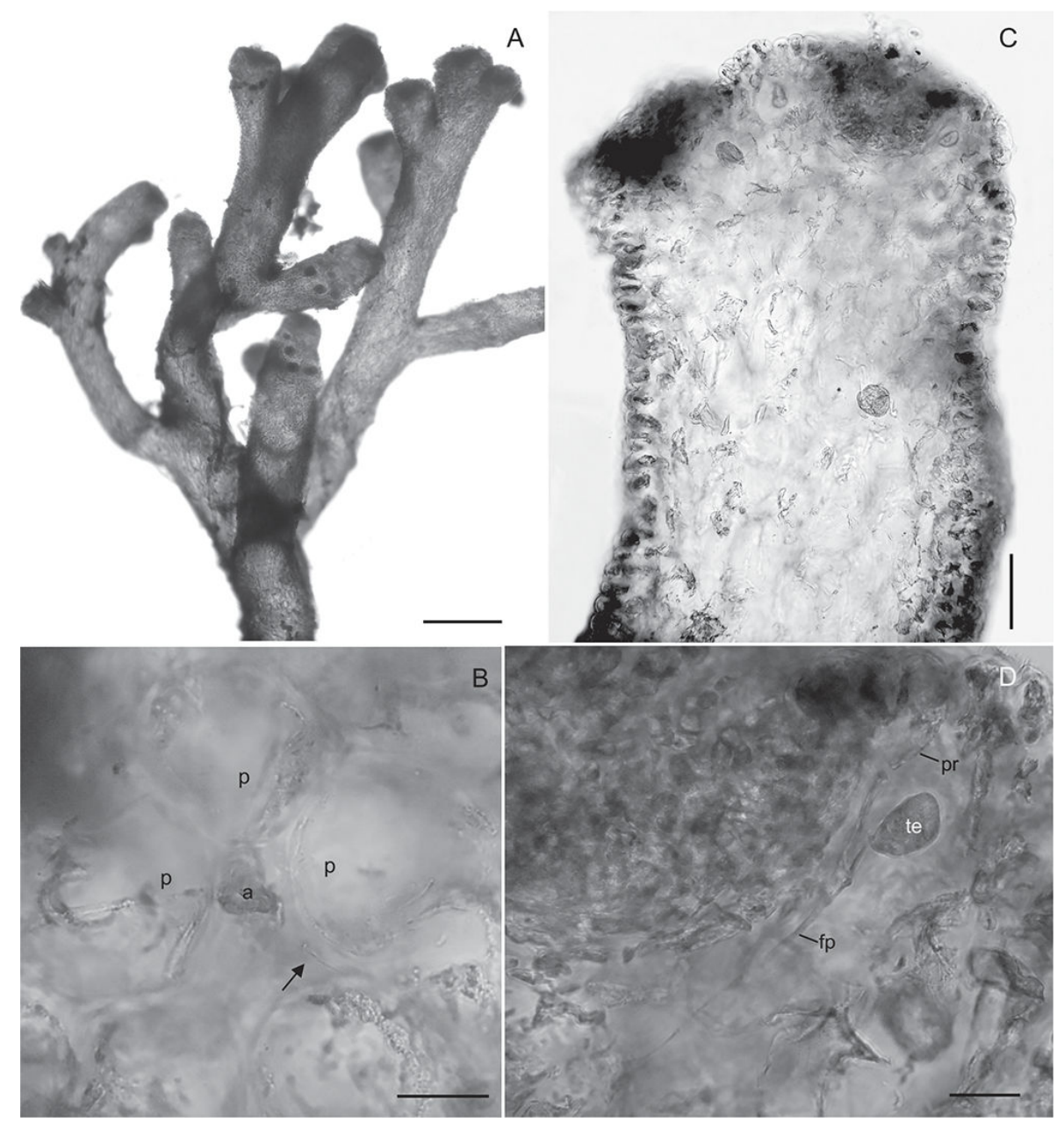

Figure 8. Laurencia digitata A) Detail of tetrasporangial branches. B) Transverse section of two superimposed tetrasporangial segments showing an axial cell (a) and one fertile pericentral cell, the fourth (arrow); the other pericentral cells (p) remain sterile (pit connections between axial and pericentral cells, out of focus). C) Longitudinal section through a tetrasporangial branchlet showing parallel arrangement of tetrasporangia. D) Detail of fertile pericentral cell (fp) with two pre-sporangial cover cells (pr, only one visualized), tetrasporangium (te); postsporangial cover cell not shown. Scale bar: A, $500 \mu \mathrm{m}$; B and D, $25 \mu \mathrm{m} ; \mathrm{C}, 40 \mu \mathrm{m}$.

Morphologically, Venezuelan Ch. anabeliae shares all diagnostic characters described for the species by Sentíes et al. (2016), such as: (i) thallus slightly compressed; (ii) two cortical cell layers, the outmost layer formed by translucent cells with conspicuous cell wall projections near the apices and absence of secondary pit connections, and the inner layer formed by pigmented and pit connected cells; and (iii) tetrasporangia produced from one additional fertile pericentral cell. The presence of $1(-2)$ crystals per cortical and subcortical cells is a characteristic unique for Ch. anabeliae from Venezuela; they were not found in Mexican Ch. anabeliae and were not described for other Chondrophycus species.

Venezuelan and South African Laurencia digitata share the cushion-like tufted habit and absence of lenticular thickenings. However, the South African material differed from ours by color (reddish-brown), branching pattern (alternate but subopposite and/or subverticillate at the tips of some branches), and absence of cortical cell walls projections near the apices (Francis et al. 2017). The tetrasporophyte has typical features of the genus Laurencia and is described for the first time for this species.

Chondrophycus anabeliae seems to be restricted to the Caribbean Sea so far. The range of distribution of Ch. anabeliae represents the limits from the western to the southeast Caribbean, whereas L. digitata, previously considered endemic to South Africa by Francis et al. (2017), presents a disjunct distribution in the Indian and Atlantic Oceans. The disjunct distribution of $L$. digitata is similar to that of $L$. natalensis whose occurrence was recorded only for the Indian Ocean, nevertheless with wider distribution [South Africa, Mozambique, Kenya, Mauritius, Sri Lanka and Vietnam (Guiry \& Guiry 2020)], and it was cited for Venezuela by García-Soto \& Lopéz-Bautista 
(2019). However, more studies of biogeography and phylogeography are needed in the area, which will allow us to explain this further.

Although macroalgal floristic studies have been carried out for the Venezuelan coast (e.g., Gómez et al. 2017), the diversity for this region is still underestimated. Similar underestimations have already been reported for other groups of red algae (e.g., Adey et al. 2015, Basso et al. 2015, Hind et al. 2015, Ardito et al. 2017, Núñez-Resendiz et al. 2018). For this reason, it is necessary to continue performing floristic surveys that incorporate molecularassisted alpha taxonomy to accurately identify all and potential new species from this region, especially for ecologically and economically important taxonomic groups such as those included in the Laurencia complex.

The use of $r b c \mathrm{~L}$ gene for phylogenetic inference, and the COI-5P barcode marker for species delimitation allied to morphological study revealed the presence of two species of the Laurencia complex for Venezuela, Chondrophycus anabeliae and Laurencia digitata. Both constitute new records for the region and their first occurrence outside the type localities. Our findings expand the geographic distribution of $\mathrm{Ch}$. anabeliae to the southeast of the Caribbean Sea, where the species seems to be restricted so far, whereas the first report of $L$. digitata for the Atlantic Ocean established a disjunct distribution of this species in the Atlantic and Indian Oceans.

\section{Acknowledgements}

We wish to thank the Faculty of Science and Technology of the University of Carabobo, Venezuela and the Faculty of Science of the Central University of Venezuela, for the field and laboratory logistical support. We also thank Marion Cordero, Yugreisy Polanco and Jorge Escobar for help with field material. We are very grateful to Michael Wynne for revising the English and for his helpful comments that improved the manuscript. VC thanks Funding from São Paulo Research Foundation (FAPESP, 2018/06085-1). VC and MTF thank Conselho Nacional de Desenvolvimento Científico e Tecnológico (CNPq, Brazil) for the Productivity Fellowship (302549/2017-0 and $304899 / 2017-8$, respectively). AS thanks the partial support of the projects: UAMI-CBS2019-2022: session 15.18-281118 and UAMI-CA-117, PRODEP.

\section{Literature cited}

Adey WH, Hernandez-Kantun JJ, Johnson G, Gabrielson, PW. 2015. DNA sequencing, anatomy, and calcification patterns support a monophyletic, subarctic, carbonate reef-forming Clathromorphum (Hapalidiaceae, Corallinales, Rhodophyta). Journal of Phycology 51: 189-203. DOI: https://doi.org/10.1111/jpy.12266
Ardito S, Núñez-Resendiz ML, Dreckmann KM, Sentíes A. 2017. Gracilaria falconii sp. nov. (Gracilariales, Rhodophyta): a new species with flat axes from Venezuela. Phytotaxa 292: 271-278. DOI: https://doi.org/ $\underline{10.11646 / \text { phytotaxa.292.3.7 }}$

Basso D, Caragnano A., Le Gall L, Rodondi G. 2015. The genus Lithophyllum in the north-western Indian Ocean, with description of L. yemenense sp. nov., L. socotraense sp. nov., L. subplicatum comb. et stat. nov., and the resumed L. affine, L. kaiseri, and L. subreduncum (Rhodophyta, Corallinales). Phytotaxa 208: 183-200. DOI: http://dx.doi.org/10.11646/phytotaxa.208.3.1

Bibi R, Cassano V, Medeiros RD, Rashid S, Rasheed M. 2019. Morphological and molecular systematic investigation of Laurencia karachiana sp. nov. (Ceramiales, Rhodophyta) from Karachi, Pakistan. Phytotaxa 404: 23-40. DOI: http://dx.doi.org/10.11646/ phytotaxa.404.1.3

Cassano V, Metti Y, Millar AJK, Gil-Rodríguez MC, Sentíes A, Díaz-Larrea J, Oliveira MC, Fujii MT. 2012a. Redefining the taxonomic status of Laurencia dendroidea (Ceramiales, Rhodophyta) from Brazil and the Canary Islands. European Journal of Phycology 47: 67-81. DOI: https://doi.org/10.1080/09670262.2011.647 $\underline{334}$

Cassano V, Oliveira MC, Gil-Rodríguez MC, Sentíes A, Díaz-Larrea J, Fujii MT. 2012b. Molecular support for the establishment of the new genus Laurenciella within the Laurencia complex (Ceramiales, Rhodophyta). Botanica Marina 55: 349-357. DOI: https://doi.org/10. $\underline{1515 / \text { bot-2012-0133 }}$

Cassano V, Santos GN, Santos EM, Nunes JMC, Oliveira MC, Fujii MT. 2019. Laurencia longiramea sp. nov. for Brazil and an emendation of the generic delineation of Corynecladia (Ceramiales, Rhodophyta). Phycologia 58: 115-127. DOI: https://doi.org/10.1080/00318884.2018.1 $\underline{523519}$

Collado-Vides L, Cassano V, Santos GN, Sentíes A, Fujii MT. 2018. Molecular and morphological characterization of Laurencia intricata and Laurenciella mayaimii sp. nov. (Ceramiales, Rhodophyta) in South Florida, USA. Phycologia 57: 287-297. DOI: https://doi.org/10.2216/ $\underline{17-80.1}$

Darriba D, Taboada GL, Doallo R, Posada D. 2012. jMoeltest2: more models, new heuristics and parallel computing. Nature Methods. 9: 772. DOI: https://doi.org/ $\underline{10.1038 / \text { nmeth.2109 }}$

Francis C, Bolton JJ, Mattio L, Mandiwana-Neudani TG, Anderson RJ. 2017. Molecular systematic reveals increased diversity within the South Africa Laurencia complex (Rhodomelaceae, Rhodophyta). Journal of Phycology. 53: 804-819. DOI: https://doi.org/10.1111/ ipy. 12543 
Freshwater DW, Rueness J. 1994. Phylogenetic relationships of some European Gelidium (Gelidiales, Rhodophyta) species, based on $r b c \mathrm{~L}$ nucleotide sequence analysis. Phycologia 33: 187-194. DOI: https://doi.org/ 10.2216/i0031-8884-33-3-187.1

Ganesan EK. 1989. A Catalog of benthic marine algae and seagrasses of Venezuela. Fondo Editorial CONICIT, Caracas, Venezuela.

Garbary D, Harper JT. 1998. A phylogenetic analysis of the Laurencia complex (Rhodomelaceae) of the red algae. Cryptogamie Algologie 19: 185-200.

García-Soto G, Lopéz-Bautista JM. 2019. Laurencia natalensis (Ceramiales, Rhodophyta): a new record for the Atlantic Ocean. Caribbean Journal of Science 49: 201-208. DOI: https://doi.org/10.18475/cjos.v49i2.a9

Gómez S, García M, Carballo Y, Gil N. 2017. Macroalgas bénticas del Parque Nacional Archipiélago Los Roques, Venezuela. Guía ilustrada. Venezuela, Caracas, Distrito Capital: Sello Editorial Ediciencias, UCV. ISBN: 978-980-00-2859-9

Gómez S, Carballo YB, García M, Gil N. eds. 2020. Web Ficoflora Venezuela. Catálogo Digital de la Ficoflora de Venezuela. Publicación electrónica. Caracas, Venezuela: Universidad Central de Venezuela, http://www.ciens. ucv.ve/ficofloravenezuela/ (accessed April 06, 2020).

Guiry MD, Guiry GM. 2020. AlgaeBase. World-wide electronic publication. National University of Ireland, Galway. http://www.algaebase.org/ (accessed March 07, 2020).

Hall TA. 1990. BioEdit: a user-friendly biological aligment editor and analysis program for Windows 95/98/NT. Nucleic Acids Symposium Series 41: 95-98.

Hernández OE, Sentíes A, Dreckmann KM, Cassano V, Fujii MT. 2017. Species diversity and biogeographical patterns of Laurencia sensu stricto (Rhodophyta) in the Atlantic Ocean. Hidrobiologica 27: 301-314. DOI: https://doi.org/10.24275/uam/izt/dcbs/hidro/2017v27n3/ Hernadez

Hind KR, Miller KA, Young M, Jensen C, Gabrielson PW, Martone PT. 2015. Resolving cryptic species of Bossiella (Corallinales, Rhodophyta) using contemporary and historical DNA. American Journal of Botany 102: 1-19. DOI: https://doi.org/10.3732/ajb.1500308

Machín-Sánchez M, Le Gall L, Neto AI, Rousseau F, Cassano V, Sentíes A, Fujii MT, Díaz-Larrea J, Prud'home van Reine W, Bonillo C, Gil-Rodríguez MC. 2014. A combined barcode and morphological approach to the systematics and biogeography of Laurencia pyramidalis and Laurenciella marilzae (Rhodophyta). European Journal of Phycology 49: 115-127. DOI: https://doi.org/10.1080/09670262.2014.893017
Machín-Sánchez M, Rousseau F, Le Gall L, Cassano V, Neto A, Sentíes A, Fujii MT, Gil-Rodríguez MC. 2016. Species diversity of the genus Osmundea (Rhodophyta, Ceramiales) in the Macaronesian Region. Journal of Phycology 52: 664-681. DOI: https://doi.org/10.1111/ jpy. 12431

Martin-Lescanne J, Rousseau F, De-Reviers B, Payri C, Couloux A, Cruaud C, Le Gall L. 2010. Phylogenetic analyses of the Laurencia complex (Rhodomelaceae, Ceramiales) support recognition of five genera: Chondrophycus, Laurencia, Osmundea, Palisada and Yuzurua stat. nov. European Journal of Phycology 45: 51-61. DOI: https://doi.org/10.1080/0967026090331429 $\underline{2}$

Metti Y, Millar AJK, Cassano V, Fujii MT. 2013. Australian Laurencia majuscula (Rhodophyta, Rhodomelaceae) and the Brazilian Laurencia dendroidea are conspecific. Phycological Research 61: 98-104. DOI: https://doi.org/ $\underline{10.1111 / \text { pre. } 12009}$

Metti Y, Millar AJK, Steinberg P. 2015. A new molecular phylogeny of the Laurencia complex (Rhodophyta, Rhodomelaceae) and a review of key morphological characters result in a new genus, Coronaphycus, and a description of C. novus. Journal of Phycology 51: 929-942. DOI: https://doi.org/10.1111/jpy.12333

Miller MA, Pfeiffer W, Schwartz T. 2010. Creating the CIPRES Science Gateway for inference of large phylogenetic trees. In: Proceedings of the Gateway Computing Environments Workshop (GCE). New Orleans, LA: The Institute of Electrical and Electronics Engineers (IEEE), pp. 1-8. DOI: https://doi.org/10.1109/ GCE.2010.5676129

Nam KW. 2007. Validation of the generic name Palisada (Rhodomelaceae, Rhodophyta). Algae 22: 53-55. DOI: https://doi.org/10.4490/ALGAE.2007.22.2.053

Nam KW, Maggs CA, Garbary DJ. 1994. Resurrection of the genus Osmundea with an emendation of the generic delineation of Laurencia (Ceramiales, Rhodophyta). Phycologia 33: 384-395. DOI: https://doi.org/10.2216/ i0031-8884-33-5-384.1

Nguyen LT, Schmidt HA, Von-Haeseler A, Minh BQ. 2015. IQ-TREE: A fast and effective stochastic algorithm for estimating maximum likelihood phylogenies. Molecular Biology and Evolution 32: 268-274. DOI: https://doi.org/ $\underline{10.1093 / \mathrm{molbev} / \mathrm{msu} 300}$

Núñez-Resendiz ML, Ardito S, Léón-Tejera H, Dreckmann KM, Sentíes A. 2018. Solieria incurvata (Solieriaceae, Rhodophyta), a new species from Venezuela based on morpho-anatomical and molecular evidence. Botanica Marina 61: 383-393. DOI: https://doi.org/10.1515/bot$\underline{\text { 2018-0010 }}$ 
Rodríguez de Ríos N. 1979. El género Laurencia Lamouroux en Venezuela. Maracay, Venezuela: Promotional Report, Facultad de Agronomía, Universidad Central de Venezuela.

Rodríguez de Ríos N. 1981. Dos especies nuevas de Laurencia (Rhodophyta, Ceramiales). Ernstia 2: 1-11.

Ronquist F, Teslenko M, Mark P, Ayres DL, Darling A, Hohna A, Larget B, Liu L, Suchard MA, Huelsenbeck JP. 2012. MrBayes 3.2: Efficient Bayesian Phylogenetic Inference and Model choice across a large model space. Systematic Biology 61: 539-542. DOI: https://doi.org/ 10.1093/sysbio/sys029

Rousseau F, Gey D, Kurihara A, Maggs CA, MartinLescanne J, Payri C, De Reviers B, Sherwood A, Le Gall L. 2017. Molecular phylogenies support taxonomic revision of three species of Laurencia (Rhodomelaceae, Rhodophyta), with the description of a new genus. European Journal of Taxonomy 269: 1-19. DOI: https:// doi.org/10.5852/ejt.2017.269

Saunders GW. 2005. Applying DNA barcoding to red macroalgae: a preliminary appraisal holds promise for future applications. Philosophical Transactions of Royal Society of Biological Sciences 360: 1879-1888. DOI: https://doi.org/10.1098/rstb.2005.1719

\footnotetext{
Associate editor: José Antonio Zertuche González

Author contributions: VC, conceptualization, field work, formal analysis, investigation, writing - original draft preparation, project administration, funding acquisition; LPS, investigation, writing reviewing and editing; BEVV, investigation, writing - reviewing and editing; SA, field work, investigation, writing - reviewing and editing; SG, investigation, writing- reviewing and editing; AS, field work, investigation, writing - reviewing and editing; MTF, field work, investigation, writing - reviewing and editing.
}

Sentíes A, Cassano V, Dreckmann KM, Gil-Rodríguez MC, Stein EM, Fujii MT. 2016. Chondrophycus anabeliae (Rhodomelaceae, Ceramiales), a new species in the Laurencia complex from the Mexican Caribbean. Phytotaxa 283: 259-270. DOI: http://dx.doi.org/10.116 46/phytotaxa.283.3.2

Sentíes A, Dreckmann KM, Hernández OE, NúñezResendiz ML, Le Gall L, Cassano V. 2019. Diversity and distribution of Laurencia sensu stricto (Rhodomelaceae, Rhodophyta) from the Mexican Pacific, including $L$. mutueaesp. nov. Phycological Research 67: 1-12. DOI: https://doi.org/10.1111/pre.12382

Swofford D. 2002. PAUP 4.0 b10: Phylogenetic analysis using parsimony. Massachusetts, USA: Sinauer Associates, Sunderland.

Thiers B. 2020. Index Herbariorum: a global directory of public herbaria and associated staff. New York Botanical Garden's Virtual Herbarium. http://www.nybg.org/bsci/ ih/ih.html (accessed September 16, 2019).

Wynne MJ. 2017. A checklist of benthic marine algae of the tropical and subtropical Western Atlantic: fourth revision. Nova Hedwigia Beiheft 145: 1-202. ISBN: 978-3-443-51067-1 
Appendix 1. Taxa used in this study for molecular analysis.

\begin{tabular}{|c|c|c|c|}
\hline \multirow{2}{*}{ Samples } & \multirow{2}{*}{ Collection data } & \multicolumn{2}{|c|}{ GenBank accession numbers } \\
\hline & & COI-5P & $r b c \mathbf{L}$ \\
\hline Chondria baileyana (Montagne) Harvey & $\begin{array}{l}\text { Canada, Nova Scotia, Pomquet (far on Monks Head Road), } 16 \text { Aug. } \\
\text { 2012, G.W. Saunders, A. Savoie, C. Longtin, K. Dixon, M. Bruce }\end{array}$ & KU564345 & - \\
\hline C. californica (Collins) Kylin & $\begin{array}{l}\text { USA, California, San Diego Co., Beach Club Reef (La Jolla Shores), } \\
1 \text { Jul. 1996, M. Volovsek }\end{array}$ & - & AY172578 \\
\hline C. collinsiana M.A. Howe & $\begin{array}{l}\text { Brazil, Rio de Janeiro, Armação dos Búzios, Praia Rasa, } 13 \text { Jan. 2005, } \\
\text { V. Cassano, J.C. De-Paula }\end{array}$ & - & GU330225 \\
\hline C. dasyphylla (Woodward) C. Agardh & USA, North Carolina, Carteret Co., Bogue Sound & - & U04021 \\
\hline $\begin{array}{l}\text { Chondrophycus anabeliae Sentíes, } \\
\text { M.T.Fujii, Cassano \& Dreckmann }\end{array}$ & $\begin{array}{l}\text { Mexico, Quintana Roo, Isla Mujeres, Garrafón de Castilla, } 12 \text { Feb. } \\
\text { 2007, A. Sentíes, M.C. Gil-Rodríguez }\end{array}$ & MN597440 & KX815262 \\
\hline Ch. anabeliae & $\begin{array}{l}\text { Venezuela, Estado Falcón, Parque Nacional Morrocoy, Cayo Muerto, } \\
19 \text { May 2015, S. Ardito. M.T. Fujii, A. Sentíes, V. Cassano }\end{array}$ & $\begin{array}{l}\text { MN597438 } \\
\text { MN597439 }\end{array}$ & $\begin{array}{l}\text { MN597441 } \\
\text { MN597442 }\end{array}$ \\
\hline Ch. dotyi (Y. Saito) K.W. Nam & USA, Hawaii & HQ423050 & - \\
\hline Ch. dotyi & USA, Hawaii, Oahu, Sandy Beach, 31 May 2015, E.M. Stein & - & KX815263 \\
\hline $\begin{array}{l}\text { Ch. cf. undulatus (Yamada) Garbary \& } \\
\text { J.T. Harper }\end{array}$ & New Caledonia, Loyalty Is., Maré, 22 Mar. 2005, C. Payri & - & FJ785307 \\
\hline Ch. cf. undulatus & USA, Maui, 12 Dec. 2007 & GU223886 & - \\
\hline Ch. cf. undulatus & USA, Hawaii & $\begin{array}{l}\text { HQ422752 } \\
\text { HQ423055 } \\
\text { HQ422996 }\end{array}$ & - \\
\hline Ch. succisus (A.B. Cribb) K.W. Nam & USA, Molokai, 11 Feb. 2007 & GU223884 & - \\
\hline Ch. tronoi (E. Ganzon-Fortes) K.W. Nam & Philippines, A.O. Lluisma & - & AF489864 \\
\hline Ch. sp. & $\begin{array}{l}\text { Australia, Norfolk Island, Collins Head, } 21 \text { Mar. 2005, Y. Metti, A. } \\
\text { Millar }\end{array}$ & & KY120337 \\
\hline Ch. sp. 1 & New Caledonia, Loyalty Is., Lifou, 26 Mar. 2005, C. Payri & - & FJ785309 \\
\hline Ch. sp. 2 & New Caledonia, Loyalty Is., Maré, 21 Mar. 2005, C. Payri & - & FJ785310 \\
\hline Ch. sp. 3 & $\begin{array}{l}\text { New Caledonia, Loyalty Is., Beautemps/Beaupré, } 06 \text { Apr. 2005, C. } \\
\text { Payri }\end{array}$ & - & FJ785311 \\
\hline Corynecladia clavata J. Agardh & $\begin{array}{l}\text { Australia, Victoria, Walkerville, } 20 \text { Jan. 2015, P. Díaz-Tapia, M. } \\
\text { Brookes }\end{array}$ & - & MF094079 \\
\hline C. clavata & $\begin{array}{l}\text { Australia, Victoria, The Caves, } 21 \text { Jan. 2015, P. Díaz-Tapia, M. } \\
\text { Brookes }\end{array}$ & MH704456 & - \\
\hline C. clavata (as Ceramiales sp.) & Australia, Tasmania, 24 Jan. 2004, G.W. Saunders, R. Withall & HM915955 & - \\
\hline $\begin{array}{l}\text { C. elata (C. Agardh) Cassano, M.C. } \\
\text { Oliveira \& M.T. Fujii }\end{array}$ & Australia, Western Australia, Rottnest Island, 15 Nov. 2008, J. Eu & - & KY120339 \\
\hline $\begin{array}{l}\text { C. nova (Metti) Cassano, M.C. Oliveira } \\
\text { \& M.T. Fujii }\end{array}$ & $\begin{array}{l}\text { Australia, NSW, Jervis Bay, Plantation Point, } 15 \text { Feb. 2005, Y. Metti, } \\
\text { A. Millar }\end{array}$ & - & KY120340 \\
\hline Laurencia aldingensis & $\begin{array}{l}\text { Brazil, Rio de Janeiro, Armação dos Búzios, Praia Rasa, } 13 \text { Jan. 2005, } \\
\text { V. Cassano, J.C. De-Paula }\end{array}$ & - & JF810351 \\
\hline $\begin{array}{l}\text { L. alfredensis Francis, Bolton, Mattio \& } \\
\text { Anderson }\end{array}$ & South Africa, 04 Jul. 2008, R.J. Anderson, J.J. Bolton & - & KY927749 \\
\hline L. brachyclados Pilger & USA, Hawaii & HQ423046 & - \\
\hline
\end{tabular}




\begin{tabular}{|c|c|c|c|}
\hline \multirow{2}{*}{ Samples } & \multirow{2}{*}{ Collection data } & \multicolumn{2}{|c|}{ GenBank accession numbers } \\
\hline & & COI-5P & $r b c \mathbf{L}$ \\
\hline L. cf. brongiartii J. Agardh & Australia, Tarcoola Beach, 1996, S. Fredericq & - & EF061654 \\
\hline L. caduciramulosa Masuda \& Kawaguchi & $\begin{array}{l}\text { Brazil, Rio de Janeiro, Angra dos Reis, Praia do Velho, } 19 \text { Apr. 2006, } \\
\text { V. Cassano, J.C. De-Paula }\end{array}$ & - & KJ700865 \\
\hline L. caraibica P.C. Silva & Mexico, Quitana Roo, Cancún, Isla Mujeres, 2006, A. Sentíes & - & EF658642 \\
\hline L. caraibica & Venezuela, Falcon, Cabo San Roman, 06 Oct. 2012, G. Garcia-Soto & & MH388533 \\
\hline $\begin{array}{l}\text { L. catarinensis Cordeiro-Marino \& M.T. } \\
\text { Fujii }\end{array}$ & $\begin{array}{l}\text { Spain, Canary Islands, Tenerife, Punta del Hidalgo, } 02 \text { Jun. 2012, } \\
\text { M.C. Gil-Rodríguez, M. Machín-Sánchez }\end{array}$ & - & KF492781 \\
\hline L. catarinensis & $\begin{array}{l}\text { Spain, Canary Islands, Lanzarote, Pechigueras, } 15 \text { Jan. 2013, M.C. } \\
\text { Gil-Rodríguez, M. Machín-Sánchez }\end{array}$ & KF492718 & - \\
\hline L. complanata (Suhr) Kützing & South Africa, 09 Dec. 2010, R.J. Anderson, J.J. Bolton & - & KY927738 \\
\hline L. corymbosa J. Agardh & South Africa, 19 Aug. 2008, R.J. Anderson, J.J. Bolton & - & KY927760 \\
\hline L. dendroidea J. Agardh & $\begin{array}{l}\text { Brazil, Bahia, Lauro de Freitas, Praia Vilas do Atlântico, } 08 \text { Jan. } \\
\text { 2008, A. Oliveira }\end{array}$ & - & GU330228 \\
\hline L. dendroidea & Venezuela, Falcon, Playa Buchuacos, 06 Oct. 2012, G. Garcia-Soto & - & MH388528 \\
\hline L. dendroidea (as L. majuscula) & $\begin{array}{l}\text { Australia, NSW, Kiama Harbour, North side, } 03 \text { Apr. 2004, Y. Metti, } \\
\text { D. Williams }\end{array}$ & - & - \\
\hline L. dendroidea & $\begin{array}{l}\text { Spain, Canary Islands, La Gomera, Punta de La Dama, } 21 \text { Sept. 2009, } \\
\text { E. Aylagas, M.C. Gil-Rodríguez, M. Machín-Sánchez }\end{array}$ & KF492725 & - \\
\hline L. dendroidea & $\begin{array}{l}\text { Spain, Canary Islands, Lanzarote, Pechigueras, } 15 \text { Jan. 2013, M.C. } \\
\text { Gil-Rodríguez, M. Machín-Sánchez }\end{array}$ & KF492728 & - \\
\hline L. dendroidea (as L. majuscula) & USA, Molokai, 10 Feb. 2007 & GU223887 & - \\
\hline $\begin{array}{l}\text { L. dichotoma Francis, Bolton, Mattio \& } \\
\text { Anderson }\end{array}$ & South Africa, 22 Mar. 2011, J.J. Bolton & - & KY927786 \\
\hline $\begin{array}{l}\text { L. digitata Francis, Bolton, Mattio \& } \\
\text { Anderson }\end{array}$ & South Africa, 04 Jul. 2008, R.J. Anderson, J.J. Bolton & - & KY927748 \\
\hline L. digitata & $\begin{array}{l}\text { Venezuela, Estado Falcón, Parque Nacional Morrocoy, Cayo Muerto, } \\
19 \text { May 2015, S. Ardito, M.T. Fujii, A. Sentíes, V. Cassano }\end{array}$ & - & MN597443 \\
\hline L. flexuosa Kützing & $\begin{array}{l}\text { South Africa, S. KwaZulu-Natal, Palm Beach, } 07 \text { Feb. 2001, S. } \\
\text { Fredericq }\end{array}$ & - & AF465815 \\
\hline L.cf. flexuosa & South Africa, Eastern Cape Province, 15 Jun. 2003, O. De Clerck & KX258821 & - \\
\hline L. filiformis (C. Agardh) Montagne & $\begin{array}{l}\text { Western Australia, Geraldton, Tarcoola Beach, } 21 \text { Sept. 1995, M.H. } \\
\text { Hommersand, F.H. Hommersand }\end{array}$ & - & MH704449 \\
\hline L. galtsoffii M.A. Howe & USA, Hawaii & HQ422984 & - \\
\hline L. glomerata (Kützing) Kützing & South Africa, 03 Mar. 2009, R.J. Anderson, J.J. Bolton & - & KY927763 \\
\hline L. heteroclada Harvey f. decussata Cribb & Australia, NSW, Arrawarra headland, 28 Jul. 2004, Y. Metti & - & KY120344 \\
\hline L. intricata J.V. Lamouroux & Cuba, Ciego de Ávila, Cayo Coco, 25 Sept. 2005, M.T. Fujii & - & GU330238 \\
\hline L. intricata & $\begin{array}{l}\text { USA, Florida, Long Key, Channel } 5 \text { (ocean side), } 10 \text { Dec. 1998, B. } \\
\text { Wysor, T. Frankovich }\end{array}$ & - & AY588410 \\
\hline L. karachiana Bibi, Cassano \& Rasheed & Pakistan, Karachi, French Beach (Buleji), 13 Aug. 2018, R. Bibi & MK796229 & MK796228 \\
\hline L. cf. kuetzingii A. Millar & New Caledonia, Loyalty Is., Ouvéa, 31 Mar. 2005, C. Payri & - & FJ785322 \\
\hline
\end{tabular}


Cassano et al. / Botanical Sciences 98(4): 624-643. 2020

\begin{tabular}{|c|c|c|c|}
\hline \multirow{2}{*}{ Samples } & \multirow{2}{*}{ Collection data } & \multicolumn{2}{|c|}{ GenBank accession numbers } \\
\hline & & COI-5P & $r b c \mathbf{L}$ \\
\hline $\begin{array}{l}\text { L. laurahuertana Mateo-Cid, Mendoza- } \\
\text { González, Sentíes \& Díaz-Larrea }\end{array}$ & $\begin{array}{l}\text { Mexico, Quintana Roo, Punta Herrero, } 12 \text { Apr. 2012, A.C. Mendoza } \\
\text { González, L.E. Mateo-Cid }\end{array}$ & - & KF279401 \\
\hline $\begin{array}{l}\text { L. longiramea Cassano, G.N. Santos, } \\
\text { J.M.C. Nunes, M.C. Oliveira \& M.T. } \\
\text { Fujii }\end{array}$ & $\begin{array}{l}\text { Brazil, Espírito Santo, Anchieta, Ilhote de Ubu, } 30 \text { Jun. 2007, E.M. } \\
\text { Stein }\end{array}$ & MH704454 & - \\
\hline L. longiramea & $\begin{array}{l}\text { Brazil, Rio de Janeiro, Armação dos Búzios, Praia Rasa, } 13 \text { Jan. 2005, } \\
\text { V. Cassano, J.C. De-Paula }\end{array}$ & MH704455 & MH704451 \\
\hline L. cf. majuscula (Harvey) A.H.S. Lucas & Oman, Dhofar, Sept. 2001, M. Wynne & - & KX146184 \\
\hline L. cf. mariannensis Yamada & $\begin{array}{l}\text { New Caledonia, Lagon Sud-Ouest, Ilot Larégnère, } 11 \text { Jul. 2003, C. } \\
\text { Payri }\end{array}$ & - & FJ785313 \\
\hline L. mcdermidiae I.A. Abbott & USA, Oahu, 08 Apr. 2007 & GU223877 & - \\
\hline L. mcdermidiae & New Caledonia, Ile des Pins, 09 Nov. 2005, C. Payri & - & FJ785314 \\
\hline $\begin{array}{l}\text { L. multiclavata Francis, Bolton, Mattio \& } \\
\text { Anderson }\end{array}$ & South Africa, 29 Mar. 2010, R.J. Anderson & - & KY927766 \\
\hline $\begin{array}{l}\text { L. mutueae Sentíes, Cassano \& } \\
\text { Dreckmann }\end{array}$ & $\begin{array}{l}\text { Mexico, Guerrero, Acapulco, Isla la Roqueta, } 07 \text { Jun. 2017, A. } \\
\text { Sentíes, K.M. Dreckmann }\end{array}$ & MK182532 & MK159179 \\
\hline L. natalensis Kylin & $\begin{array}{l}\text { South Africa, S. KwaZulu-Natal, Palm Beach, } 07 \text { Feb. 2001, S. } \\
\text { Fredericq }\end{array}$ & - & AF465816 \\
\hline L. natalensis & Venezuela, Falcon, Cabo San Roman, 06 Oct. 2012, G. Garcia-Soto & & MH388523 \\
\hline L. nidifica J. Agardh & USA, Hawaii & HQ422750 & - \\
\hline L. nidifica & USA, Hawaii & HQ422751 & \\
\hline L. nidifica & USA, Hawaii & HQ423054 & - \\
\hline L. cf. nidifica & New Caledonia, Ile des Pins, 30 Nov. 2005, C. Payri & - & FJ785315 \\
\hline L. nipponica & Russia, Sakhalin, 23 Jun. 2003 & GU223874 & - \\
\hline L. obtusa (Hudson) J.V. Lamouroux & Ireland, County Donegal, Fanad Head, C.A. Maggs & - & AF281881 \\
\hline L. obtusa & $\begin{array}{l}\text { France, Languedoc-Roussillon, Pyrenees-Orientales, Cap Beart, } \\
\text { Banyuls-sur-Mer, } 11 \text { Jul. 2007, L. Bittner }\end{array}$ & KX258828 & - \\
\hline L. oliveirana Yoneshigue & $\begin{array}{l}\text { Brazil, Rio de Janeiro, Arraial do Cabo, Ponta da Cabeça, Praia } \\
\text { Grande, } 07 \text { Jul. 2008, V. Cassano, J.C. De-Paula }\end{array}$ & - & JF810352 \\
\hline L. pacifica Kylin & $\begin{array}{l}\text { USA, California, Stillwater Cove, Pebble Beach, } 20 \text { May 2010, B. } \\
\text { Clarkston, K. Hind, S. Toews }\end{array}$ & KM254466 & - \\
\hline L. pacifica & $\begin{array}{l}\text { USA, California, Moss Beach, Central Beach, } 17 \text { Feb. 1992, S. } \\
\text { Fredericq }\end{array}$ & - & AY588411 \\
\hline L. pumila (Grunow) Papenfuss & South Africa, 10 Jun. 2009, R.J. Anderson, J.J. Bolton & - & KY927765 \\
\hline $\begin{array}{l}\text { L. pumila var. dehoopiensis Francis, } \\
\text { Bolton, Mattio \& Anderson }\end{array}$ & South Africa, 19 Aug. 2008, R.J. Anderson & - & KY927757 \\
\hline L. pyramidalis Bory ex Kützing & France, Brittany, Roscoff, 05 Dec. 2002, F. Rousseau & - & FJ785316 \\
\hline L. pyramidalis & $\begin{array}{l}\text { Portugal, Madeira, Seixal, Praia da Laje, } 07 \text { Jul. 2011, E. Nogueira, V. } \\
\text { Cassano, A. Sentíes }\end{array}$ & KF492733 & - \\
\hline L. pyramidalis & $\begin{array}{l}\text { Portugal, Madeira, Porto Muniz, } 07 \text { Jul. 2011, M.T. Fujii, A. Neto, M. } \\
\text { Machín-Sánchez }\end{array}$ & KF492739 & - \\
\hline
\end{tabular}




\begin{tabular}{|c|c|c|c|}
\hline \multirow{2}{*}{ Samples } & \multirow{2}{*}{ Collection data } & \multicolumn{2}{|c|}{ GenBank accession numbers } \\
\hline & & COI-5P & $r b c \mathbf{L}$ \\
\hline L. pyramidalis & $\begin{array}{l}\text { Portugal, Azores, São Miguel, Mosteiros, } 27 \text { Jun. 2011, M.T. Fujii, A. } \\
\text { Prestes, A. Pacheco, M. Machín-Sánchez }\end{array}$ & KF492751 & - \\
\hline L. pyramidalis & $\begin{array}{l}\text { Spain, Canary Islands, Fuerteventura, Garcey, } 10 \text { Sept. 2012, M. } \\
\text { Machín-Sánchez }\end{array}$ & KF492756 & - \\
\hline L. pyramidalis & $\begin{array}{l}\text { Spain, Canary Islands, Tenerife, Puerto de La Cruz, } 20 \text { May 2011, } \\
\text { M.C. Gil-Rodríguez, M. Machín-Sánchez }\end{array}$ & KF492746 & - \\
\hline L. rigida J. Agardh & $\begin{array}{l}\text { Australia, NSW, Botany Bay, } 11 \text { May 2000, G.C. Zuccarello, J.A. } \\
\text { West }\end{array}$ & - & AY920852 \\
\hline L. saitoi Perestenko & $\begin{array}{l}\text { USA, California, Monterey, McAbee Beach, } 21 \text { May 2010, B. } \\
\text { Clarkston, K. Hind, S. Toews }\end{array}$ & KM254876 & - \\
\hline $\begin{array}{l}\text { L. snackeyi (Weber van Bosse) M. } \\
\text { Masuda }\end{array}$ & Unspecified & MF093985 & - \\
\hline $\begin{array}{l}\text { L. sodwaniensis Francis, Bolton, Mattio } \\
\text { \& Anderson }\end{array}$ & South Africa, 22 Mar. 2011, C.M. Francis & - & KY927790 \\
\hline $\begin{array}{l}\text { L. stegengae (Stegenga, Bolton \& } \\
\text { Anderson) Francis, Bolton, Mattio \& } \\
\text { Anderson }\end{array}$ & South Africa, 18 Mar. 2010, R.J. Anderson & - & KY927743 \\
\hline L. tasmanica J.D. Hooker \& Harvey & $\begin{array}{l}\text { Australia, Victoria, Tween Reef, between Cape Paterson and } \\
\text { Inverloch, P. Díaz-Tapia }\end{array}$ & - & MF094081 \\
\hline L. venusta Yamada & $\begin{array}{l}\text { Mexico, Quintana Roo, Puerto Morelos, Punta Brava, 2004, J. Díaz- } \\
\text { Larrea, A. Sentíes }\end{array}$ & - & EF061655 \\
\hline L. viridis Gil-Rodríguez \& Haroun & $\begin{array}{l}\text { Spain, Canary Islands, Tenerife, Punta del Hidalgo, Roca Negra, } 06 \\
\text { Oct. 2005, M.C. Gil-Rodríguez }\end{array}$ & - & EF685999 \\
\hline L. viridis & $\begin{array}{l}\text { Spain, Canary Islands, Fuerteventura, El Cotillo, } 07 \text { Mar. 2011, M.C. } \\
\text { Gil-Rodríguez }\end{array}$ & KF492757 & - \\
\hline L. viridis & $\begin{array}{l}\text { Portugal, Azores, Santa Maria, Boca de Ribeira Seca, } 02 \text { Jul. 2011, } \\
\text { M.T. Fujii, A. Neto, J. Pombo, M. Machín-Sánchez }\end{array}$ & KF492760 & - \\
\hline "L. yamadana" M.A. Howe & USA, HI, Maui, Kihei, 05 Apr.2006, A.L. Carlile, J.R.Waaland & - & GQ252550 \\
\hline Laurencia sp. & New Caledonia, Loyalty Islands, Maré, 21 Mar. 2005, C. Payri & KX258820 & KX146182 \\
\hline Laurencia sp. & New Caledonia, Loyalty Islands, Maré, 19 Mar. 2005, C. Payri & KX258819 & - \\
\hline Laurencia sp. & USA, Oahu & $\begin{array}{l}\text { GU223889 } \\
\text { GU223891 } \\
\text { GU223893 } \\
\text { GU223894 }\end{array}$ & - \\
\hline Laurencia sp. & USA, Lanai & GU223892 & - \\
\hline Laurencia sp. & Sri Lanka, Odayapiti lagoon, 08 Nov. 2006, E. Coppejans & KX258826 & - \\
\hline Laurencia sp.1 & Australia, Victoria, Mallacoota, H. Verbruggen, K.Dixon & - & MK125344 \\
\hline Laurencia sp.2 & Australia, Victoria, Mallacoota, H. Verbruggen, K. Dixon & - & MK125395 \\
\hline $\begin{array}{l}\text { Laurenciella marilzae (Gil-Rodríguez et } \\
\text { al.) Gil-Rodríguez et al. }\end{array}$ & $\begin{array}{l}\text { Spain, Canary Islands, Tenerife, Punta del Hidalgo, } 12 \text { Jul. 2006, } \\
\text { M.C. Gil-Rodríguez, M.T. Fujii, A. Sentíes }\end{array}$ & - & EF686002 \\
\hline La. marilzae & $\begin{array}{l}\text { Spain, Canary Islands, Lanzarote, Pechigueras, } 15 \text { Jan. 2013, M.C. } \\
\text { Gil-Rodríguez, M. Machín-Sánchez }\end{array}$ & KF492762 & - \\
\hline
\end{tabular}




\begin{tabular}{|c|c|c|c|}
\hline \multirow{2}{*}{ Samples } & \multirow{2}{*}{ Collection data } & \multicolumn{2}{|c|}{ GenBank accession numbers } \\
\hline & & COI-5P & $r b c \mathbf{L}$ \\
\hline La. marilzae & $\begin{array}{l}\text { Portugal, Azores, São Miguel, Cerco da Caloura-Baía, E. Nogueira, } \\
\text { V. Cassano, A. Sentíes }\end{array}$ & KF492765 & - \\
\hline La. marilzae & $\begin{array}{l}\text { Spain, Canary Islands, Tenerife, Punta del Hidalgo, } 13 \text { Jan. 2012, } \\
\text { M.C. Gil-Rodríguez, M. Machín-Sánchez }\end{array}$ & KF492769 & - \\
\hline La. marilzae & $\begin{array}{l}\text { Brazil, São Paulo, Laje de Santos Marine State Park, Parcel do Sul, } 25 \\
\text { Mar. 2007, R. Rocha-Jorge }\end{array}$ & KF270693 & GU938189 \\
\hline La. marilzae & Croatia, Scedro, 11 Jun. 2007, J. Utge, L. Le Gall & KX258829 & KX146186 \\
\hline La. mayaimii L. Collado-Vides, Cassano & USA, Florida, Biscayne Bay at Deering Estate, 12 Aug. 2013, L. & MG004176 & - \\
\hline \& M.T. Fujii & Collado-Vides, V. Cassano, M.T. Fujii & MG004177 & \\
\hline La. mayaimii & $\begin{array}{l}\text { USA, Florida, Key Largo, John Pennekamp Park, } 14 \text { Aug. 2013, L. } \\
\text { Collado-Vides, V. Cassano, M.T. Fujii }\end{array}$ & MG004178 & MG004183 \\
\hline Laurenciella sp. & $\begin{array}{l}\text { USA, Florida, Key Biscayne, Crandon Park, } 12 \text { Aug. 2013, L. } \\
\text { Collado-Vides, V. Cassano, M.T. Fujii }\end{array}$ & MG004179 & MG004184 \\
\hline $\begin{array}{l}\text { Ohelopapa flexilis (Setchell) F. Rousseau, } \\
\text { Martin-Lescanne, Payri \& L. Le Gall }\end{array}$ & French Polynesia, Tahiti, Tahara reef, 24 Mar. 2007, A. Apham & KX258830 & KX146187 \\
\hline $\begin{array}{l}\text { Osmundea blinksii (Hollenberg \& I.A. } \\
\text { Abbott) K.W. Nam }\end{array}$ & $\begin{array}{l}\text { USA, California, San Mateo Co., Año Nuevo, Greyhound Rock, } 17 \\
\text { Jul.1996, M.H. Hommersand }\end{array}$ & - & AY172575 \\
\hline $\begin{array}{l}\text { O. caspica (Zinova \& Zaberzhinskaya) } \\
\text { Maggs \& L.M. McIvor }\end{array}$ & Azerbaijan, Sangachal Bay, 01 Sept. 2003 & - & KX146188 \\
\hline O. hybrida (A.P. de Candolle) K.W. Nam & France, Brittany, St. Lunaire, 20 Mar. 1999, F. Rousseau & - & FJ785317 \\
\hline O. hybrida & France, Brittany, Roscoff, Finistere, 12 May 2002, F. Rousseau & KX258831 & - \\
\hline O. oederi (Gunnerus) G. Furnari & Ireland, Co. Donegal, St. John's Point, 12 Oct. 1999, C.A. Maggs & - & AF281880 \\
\hline $\begin{array}{l}\text { O. osmunda (S.G. Gmelin) K.W. Nam \& } \\
\text { Maggs }\end{array}$ & Ireland, Co. Donegal, St. John's Point, 12 Oct. 1999, C.A. Maggs & - & AF281877 \\
\hline O. osmunda & France, Brittany, Le Loup, 19 May 2011, L. Couceiro, M. Robuchon & KJ960875 & - \\
\hline O. pinnatifida (Hudson) Stackhouse & France, Brittany, Penmarch & - & AF259495 \\
\hline O. pinnatifida & France, Brittany, Le Loup, 08 Mar. 2012, L. Couceiro, M. Robuchon & KJ960886 & - \\
\hline $\begin{array}{l}\text { O. sanctarum M.T. Fujii \& R. Rocha- } \\
\text { Jorge }\end{array}$ & $\begin{array}{l}\text { Brazil, São Paulo, Laje de Santos Marine State Park, Parcel do Sul, } 19 \\
\begin{array}{lll}\text { Aug. } \quad 2012, \quad \text { R. } \quad \text { Rocha-Jorge, } & \text { M.B. Barros-Barreto }\end{array}\end{array}$ & - & KC012601 \\
\hline $\begin{array}{l}\text { O. sinicola (Setchell \& N.L. Gardner) } \\
\text { K.W. Nam }\end{array}$ & $\begin{array}{l}\text { USA, California, Orange Co., Crescent Beach, } 28 \text { May 2002, S. } \\
\text { Murray }\end{array}$ & - & AY588407 \\
\hline $\begin{array}{l}\text { O. spectabilis (Postels \& Ruprecht) K.W. } \\
\text { Nam var. spectabilis }\end{array}$ & $\begin{array}{l}\text { Mexico, Baja California, Punta Santo Thomas, } 02 \text { Jul. 1996, M.H. } \\
\text { Hommersand }\end{array}$ & - & AY172574 \\
\hline O. spectabilis & $\begin{array}{l}\text { USA, California, Aquarium Reef, Monterey Bay, } 23 \text { May 2010, B. } \\
\text { Clarkston, S. Toews }\end{array}$ & KM254974 & - \\
\hline O. spectabilis & $\begin{array}{l}\text { USA, California, Monterey, McAbee Beach, } 21 \text { May 2010, B. } \\
\text { Clarkston, K. Hind, S. Toews }\end{array}$ & KM254320 & - \\
\hline O. splendens (Hollenberg) K.W. Nam & $\begin{array}{l}\text { Mexico, Baja California, Drift, Bahia Colnett, } 02 \text { Jul. 1996, M.H. } \\
\text { Hommersand, J. Hughey }\end{array}$ & - & AY172576 \\
\hline O. splendens & $\begin{array}{l}\text { USA, California, Santa Cruz (Four Mile), } 19 \text { May 2010, B. Clarkston, } \\
\text { K. Hind, S. Toews }\end{array}$ & KM254377 & - \\
\hline
\end{tabular}




\begin{tabular}{|c|c|c|c|}
\hline \multirow{2}{*}{ Samples } & \multirow{2}{*}{ Collection data } & \multicolumn{2}{|c|}{ GenBank accession numbers } \\
\hline & & COI-5P & $r b c \mathbf{L}$ \\
\hline $\begin{array}{l}\text { Palisada cervicornis (Harvey) Collado- } \\
\text { Vides, Cassano \& M.T. Fujii }\end{array}$ & USA, Florida, Key Largo, Pickles Reef, 14. Aug. 2013, A. Duran & - & $\begin{array}{l}\text { MG030375 } \\
\text { MG020476 }\end{array}$ \\
\hline $\begin{array}{l}\text { P. corallopsis (Montagne) Sentíes, M.T. } \\
\text { Fujii \& Díaz-Larrea }\end{array}$ & $\begin{array}{l}\text { Mexico, Yucatán, Cancún, Chaac Mool Beach, 2005, J. Díaz-Larrea, } \\
\text { A. Sentíes }\end{array}$ & - & EF061646 \\
\hline $\begin{array}{l}\text { P. crustiformans (McDermid) A.R. } \\
\text { Sherwood, A. Kurihara \& K.W. Nam }\end{array}$ & USA, Hawaii & HQ422768 & - \\
\hline P. crustiformans & USA, Hawaii, Oahu, Makapuu, 26 May 2007, A. Kurihara & - & KX146196 \\
\hline P. flagellifera (J. Agardh) K.W. Nam & $\begin{array}{l}\text { Brazil, Rio de Janeiro, Rio das Ostras, Praia do Cemitério, } 03 \text { Aug. } \\
\text { 2005, V. Cassano, M.B.B. Barreto }\end{array}$ & - & GU330227 \\
\hline P. flagellifera & $\begin{array}{l}\text { Spain, Canary Islands, Tenerife, Punta del Hidalgo, } 13 \text { Jan. 2012, } \\
\text { M.C. Gil-Rodríguez, M. Machín-Sánchez }\end{array}$ & KF492772 & - \\
\hline $\begin{array}{l}\text { P. furcata (Cordeiro-Marino \& M.T. } \\
\text { Fujii) Cassano \& M.T. Fujii }\end{array}$ & Brazil, Paraíba, Praia de Tambaú, 24 Feb. 2004, M.T. Fujii & - & GU330226 \\
\hline P. parvipapillata (C.K. Tseng) K.W. Nam & USA, Oahu,18 Sept. 2007 & GU223895 & - \\
\hline P. perforata (Bory) K.W. Nam & $\begin{array}{l}\text { Spain, Canary Islands, Tenerife, Punta del Hidalgo, Faro, Bahia } \\
\text { Izquierda, } 06 \text { Oct. 2005, M. Gil-Rodríguez }\end{array}$ & - & EU256327 \\
\hline P. perforata & $\begin{array}{l}\text { Mexico, Quintana Roo, Isla Mujeres, 2007, A. Sentíes, M.C. Gil- } \\
\text { Rodríguez }\end{array}$ & - & EF658641 \\
\hline P. perforata & $\begin{array}{l}\text { Spain, Canary Islands, Tenerife, Punta del Hidalgo, } 13 \text { Jan. 2012, } \\
\text { M.C. Gil-Rodríguez, M. Machín-Sánchez }\end{array}$ & KF492773 & - \\
\hline P. cf. robusta (Yamada) K.W. Nam & New Caledonia, Lifou, 23 Mar. 2005, C. Payri & - & FJ785321 \\
\hline P. yamadana (M.A. Howe) K.W. Nam & USA, Hawaii & HQ422794 & - \\
\hline Palisada sp. & New Caledonia, Ilot Bayes, 01 Jan. 2001, C. Payri & - & KX146194 \\
\hline $\begin{array}{l}\text { Yuzurua poiteaui (J.V. Lamouroux) } \\
\text { Martin-Lescanne var. gemmifera } \\
\text { (Harvey) M.J. Wynne }\end{array}$ & $\begin{array}{l}\text { Mexico, Quintana Roo, Puerto Morelos, Ojo de Agua, 2004, J. Díaz- } \\
\text { Larrea, A. Sentíes }\end{array}$ & - & EF061648 \\
\hline Y. poiteaui var. gemmifera & $\begin{array}{l}\text { Cuba, La Havana, Rincon de Guanabo, 2005, J. Díaz-Larrea, A. } \\
\text { Areces }\end{array}$ & - & EF061650 \\
\hline Y. poiteaui var. poiteaui & USA, Florida, Long Key, Ovan Side, 1998, S. Fredericq & - & EF061652 \\
\hline Y. poiteaui var. poiteaui & $\begin{array}{l}\text { Mexico, Quitana Roo, Cancún, Playa del Carmen, 2005, J. Díaz- } \\
\text { Larrea, A. Sentíes }\end{array}$ & - & EF061653 \\
\hline Yuzurua sp. & $\begin{array}{l}\text { West Indies, Guadeloupe, Grand Cul-de-Sac Marin, Chenal ilet Colas, } \\
03 \text { May 2012, F. Rousseau, Y. Buske, J. Espinosa, M. Snyder, G. } \\
\text { Dirberg }\end{array}$ & KX258843 & - \\
\hline
\end{tabular}

